\title{
Performance Issues for a Changing Electric Power Industry
}

\author{
January 1995
}

\author{
Energy Information Administration \\ Office of Coal, Nuclear, Electric and Alternate Fuels \\ U.S. Department of Energy \\ Washington, DC 20585
}

This report was prepared by the Energy Information Administration, the independent statistical and analytical agency within the Department of Energy. The information contained herein should not be construed as advocating or reflecting any policy position of the Department of Energy or of any other organization. 


\section{Contacts}

This report was prepared by the staff of the Supply Analysis Branch, Analysis and Systems Division, Office of Coal, Nuclear, Electric and Alternate Fuels (CNEAF) with assistance from the Electric Data Systems Branch, Survey Management Division, CNEAF. General information regarding this publication may be obtained from Robert M. Schnapp, Director, Analysis and Systems Division (202/254-5392), or Betsy O'Brien, Chief, Supply Analysis Branch (202/254-5490). Specific questions regarding the preparation and content of the report may be directed to Art Fuldner, project manager of the publication (202/254-5321). Larry Spancake (202/2545344) may be contacted for specific information on the changing structure of the electric power industry and the economics of electric power reliability. Robin Reichenbach (202/254-5353) may be contacted for specific information on historical and current reliabilityrelated data.

\section{Acknowledgements}

The Energy Information Administration gratefully acknowledges the assistance of S. L. Daniel, Jr., David R. Nevius, and David A. Whiteley of the North American Electric Reliability Council, Charles D.
Siebenthal of the Electric Power Research Institute, Michael A. Crew of Rutgers University, and Paul R. Kleindorfer of the University of Pennsylvania. 


\section{DISCLAIMER}

This report was prepared as an account of work sponsored by an agency of the United States Government. Neither the United States Government nor any agency thereof, nor any of their employees, make any warranty, express or implied, or assumes any legal liability or responsibility for the accuracy, completeness, or usefulness of any information, apparatus, product, or process disclosed, or represents that its use would not infringe privately owned rights. Reference herein to any specific commercial product, process, or service by trade name, trademark, manufacturer, or otherwise does not necessarily constitute or imply its endorsement, recommendation, or favoring by the United States Government or any agency thereof. The views and opinions of authors expressed herein do not necessarily state or reflect those of the United States Government or any agency thereof. 


\section{DISCLAIMER}

Portions of this document may be illegible in electronic image products. Images are produced from the best available original document. 


\section{Preface}

Section 205(a)(2) of the Department of Energy Organization Act of 1977 (Public Law 95-91) requires the Administrator of the Energy Information Administration (EIA) to carry out a central, comprehensive, and unified energy data information program that will collect, evaluate, assemble, analyze, and disseminate data and information relevant to energy resources, reserves, production, demand, technology, and related economic and statistical information. To assist in meeting these responsibilities in the area of electric power, EIA has prepared this report, Performance Issues for a Changing Electric Power Industry. The purpose of this report is to provide an overview of some of the factors affecting reliability within the electric bulk power system. Historical and projected data related to reliability issues are discussed on a national and regional basis. Current research on economic considerations associated with reliability levels is also reviewed.

The legislation that created the EIA vested the organization with an element of statutory independence. The EIA does not take positions on policy questions. The EIA's responsibility is to provide timely, high-quality information and to perform objective, credible analyses in support of deliberations by both public and private decisionmakers. Accordingly, this report does not purport to represent the policy positions of the U.S. Department of Energy or the Administration. 



\section{Contents}

Highlights $\ldots \ldots \ldots \ldots \ldots \ldots \ldots \ldots \ldots \ldots \ldots \ldots \ldots \ldots \ldots \ldots \ldots \ldots \ldots \ldots \ldots \ldots \ldots \ldots \ldots \ldots \ldots \ldots$

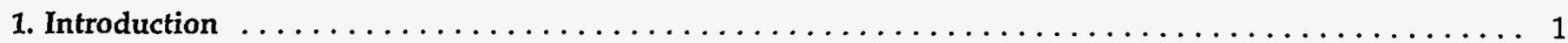

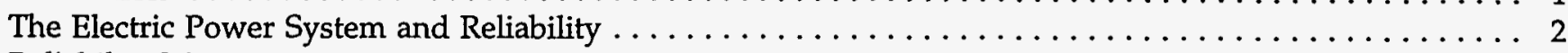

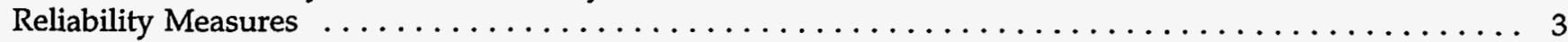

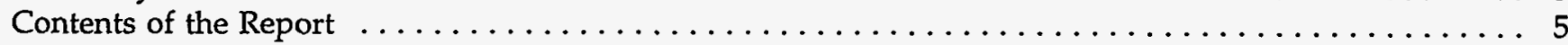

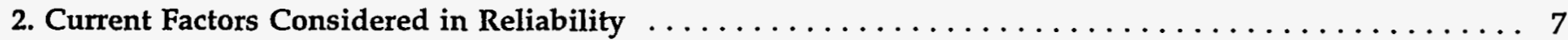

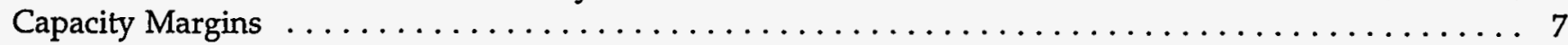

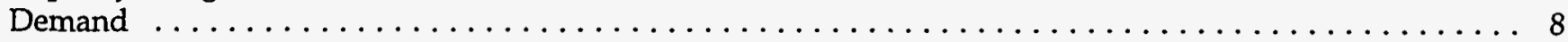

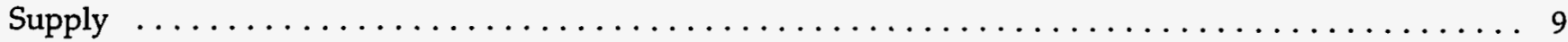

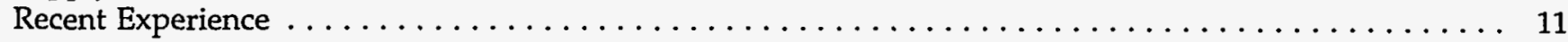

3. The Changing Structure and the Reliability of the Electric Power Industry $\ldots \ldots \ldots \ldots \ldots \ldots$

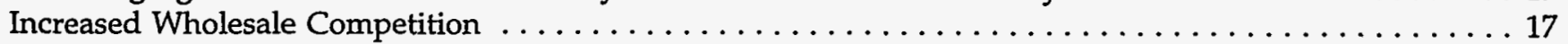

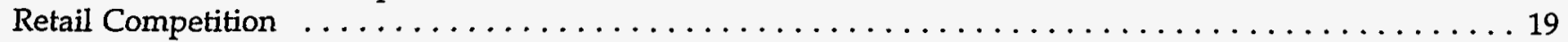

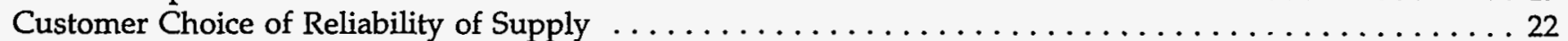

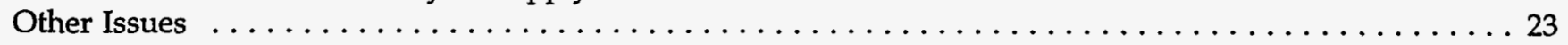

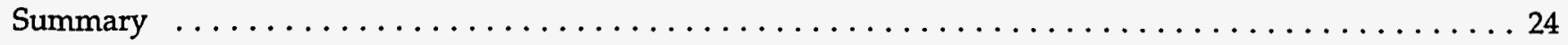

Appendices

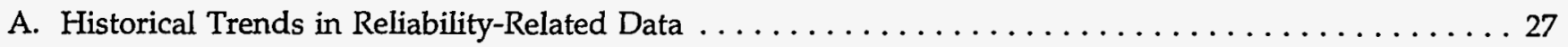

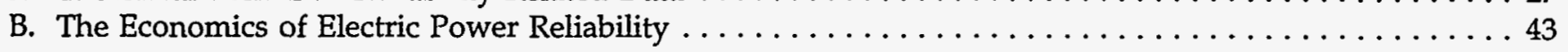

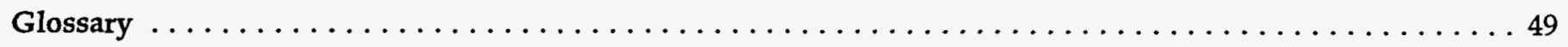




\section{Tables}

1. NERC Regional Criteria for Assessing Adequacy of Generating Capacity . . . . . . . . . . . . . . 8

2. Selected Winter Peak Demand Records, Week Ending January 22, 1994 . . . . . . . . . . . . . . . . . . . 14

3. Pennsylvania-New Jersey-Maryland Interconnection Assessment for January 19, 1994 . . . . . . . . . . . . 16

\section{Figures}

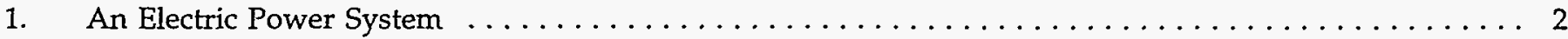

2. Regions and Interconnections of the North American Electric Reliability Council in the Contiguous

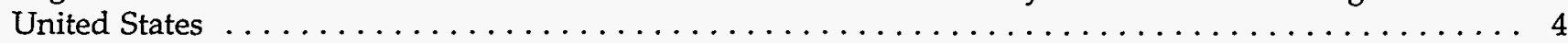

3. Variation of Customers' Costs with Capacity Margin $\ldots \ldots \ldots \ldots \ldots \ldots$

4. Natural Gas Consumption for Electricity Production, 1989-1993 . . . . . . . . . . . . . . . . . . . . . . . 9

5. Nonutility Share of Total U.S. Electricity Generation, 1973-1993 . . . . . . . . . . . . . . . . . . . . . . 10

6. Percent of Major U.S. Electric System Disturbances and Unusual Occurrences by Cause of Outage,

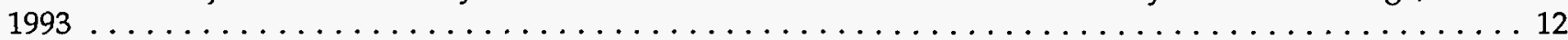

7. Selected Winter Peak Demand Records, Week Ending January 22, 1994 . . . . . . . . . . . . . . . . . 15

8. Projected vs. Actual Demand and Supply for the Pennsylvania-New Jersey-Maryland

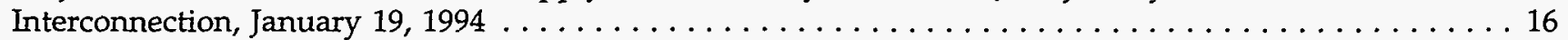

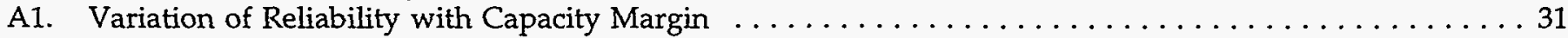

A2. U.S. Capacity Margin, $1973-1993 \ldots \ldots \ldots \ldots \ldots \ldots \ldots \ldots \ldots \ldots$

A3. Projected Capacity Margin for the Eastern United States by NERC Region, 1994-2003 . . . . . . . . . . 32

A4. Projected Capacity Margin for the Western United States by NERC Region, 1994-2003 . . . . . . . . . . 32

A5. Annual Net Additions in Net Summer Capability and Summer Peak Demand, 1973-1993 . . . . . . . . . 33

A6. Annual Percentage Change in Electricity Sales, 1973-1993 . . . . . . . . . . . . . . . . . . . . . 33

A7. Projected Annual Net Additions in Net Summer Capability and Summer Peak Demand, 1994-2003 ... . 33

A8. Actual vs. Projected Summer Peak Demand, 1978-1993 . . . . . . . . . . . . . . . . . . . . . . . . 34

A9. Difference Between One-Year Forecast and Actual Summer Peak Demand as a Percentage of Actual

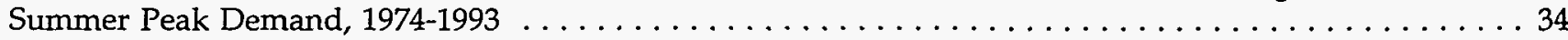

A10. Estimated Utility Demand-Side Management Energy Savings, 1989-1993 . . . . . . . . . . . . . . . . . 35

A11. Demand-Side Management Load Objectives . . . . . . . . . . . . . . . . . . . . . . . . . 35

A12. Utility Net Summer Capability by Prime Mover, 1973-1993 . . . . . . . . . . . . . . . . . . . . . . . . 36

A13. Utility Natural Gas Receipts by Contract Type and Interconnection, 1993 . . . . . . . . . . . . . . . 36

A14. Nameplate Capacity of Utility Fossil-Fuel Steam Units and Nuclear Units by Age, 1993 . . . . . . . . . 37

A15. Proposed Utility Repowering and Plant Betterment, 1994-2003 . . . . . . . . . . . . . . . . . . . . . . 37

A16. Utility Nameplate Capacity Affected by Phase I of CAAA90 by Compliance Method . . . . . . . . . . . 37

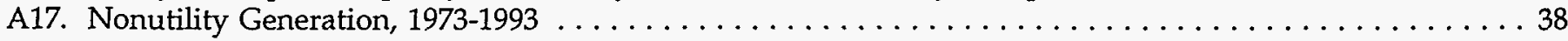

A18. Nonutility Nameplate Capacity by Prime Mover, 1985-1993 . . . . . . . . . . . . . . . . . . . . . . . . . 38

A19. U.S. Wholesale Receipts and Sales to Ultimate Consumers of Electricity for Investor-Owned

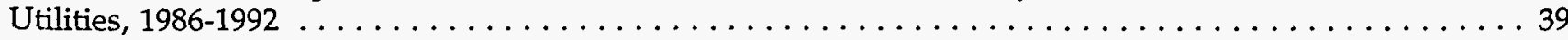

A20. U.S. Electricity Trade with Canada and Mexico, 1973-1993 . . . . . . . . . . . . . . . . . . . . . 39 


\section{Highlights}

One of the compelling topics currently facing the electric power industry is the prospect of substantial change in its structure and organization resulting from more competition, similar to the dramatic changes which have taken place in the telecommunications and natural gas industries. ${ }^{1}$ Furthermore, while not related to changes in industry structure or organization, the January 1994 cold wave that resulted in the implementation of emergency actions, involving rotating consumer blackouts in the eastern United States, increased the awareness of electricity reliability issues. Together these two topics raise the question: Will the changing structure of the electric power industry affect reliability?

The U.S. electric power system is one of the most reliable systems in the world. ${ }^{2}$ Most disturbances that affect consumers are caused by adverse weather conditions affecting the electric distribution system. The cost of avoiding distribution system outages is very high. Greater reliability in the electric power system almost always comes at a cost. This report addresses the reliability of the bulk power electric system, which consists of electric generating plants and the transmission network.

\section{Reliability Factors in a Changing Structure}

Reliability for an electric system is, most simply, the extent to which consumers can obtain electricity from the system in the amount they want. In order to provide electricity to consumers in a reliable manner, organizations that generate and transmit electricity must ensure that the generating and transmission line capacities are adequate to meet demand. They must also ensure that the proper operating procedures for the bulk power system are followed. This report focuses primarily on the adequacy of the generating capacity for the bulk power system, particularly in view of the changing structure of the electricity industry.

One of the most commonly used measures in planning for adequate generating capacity reliability is capacity margins. Capacity margins indicate "the amount of generating capacity available to provide for scheduled maintenance, emergency outages, system operating requirements, and unforeseen electricity demand. ${ }^{\prime 3}$ They offer one of the simplest indications of how much generating capacity would be available above the projected peak demand if all capacity were on-line.

The aggregate U.S. capacity margin (including both utilities and the grid-serving portion of nonutilities) has shown a declining trend since 1982 , from 33 percent to 21 percent in 1993. Although this drop seems dramatic, the decline must be viewed in its historical context. In the 1970's, the forecasted peak demand was much larger than the peak demand that actually occurred. Therefore, utilities had planned and built more capacity than was actually needed by the time the capacity was completed. This caused quite high capacity margins. Because of these higher margins, utilities were able to minimize the use of higher fuel cost generating units. However, these high margins were not necessary for the level of reliability deemed acceptable and in recent years have been declining towards more efficient levels.

As the industry evolves, the decision of what constitutes adequate reliability for a consumer may increasingly be made by the customers instead of the utilities. This may occur as customers are allowed to choose among suppliers, referred to as retail wheeling, and decide if they are willing to pay for backup capacity or have their service interrupted if their supplier is not able to provide sufficient electric power to the transmission network at any given time. As many as nine States are already considering retail wheeling legislation.

Some decisions about the planned level of reliability are already being ceded to the customer as the industry evolves. Utilities have long had programs that allow a small number of their customers to affect the level of reliability of their own electric power service. These programs all allow the customer to choose a set of conditions under which his electricity service may be interrupted. In recent years, particularly with the advent of demand-side management and cheaper metering costs, these programs have become more popular and have

\footnotetext{
'See Robert W. Crandall, After the Breakup: U.S. Telecommunications in a More Competitive Era (Washington, DC: The Brookings Institution, 1991) and Energy Information Administration, Natural Gas 1994: Issues and Trends, DOE/EIA-0560(94) (Washington, DC, July 1994).

${ }^{2}$ North American Electric Reliability Council, NERC 2000 (Princeton, NJ, September 30, 1994), p. 2.

${ }^{3}$ North American Electric Reliability Council, Electricity Supply \& Demand 1993-2002 (Princeton, NJ, June 1993 ), p. 12.
} 
been extended to more customers. With the introduction of competition into the industry, the option of purchasing a desired level of reliability could be even more accessible to customers. It should be noted, however, that the responsibility for operation of the bulk power system needs to remain with some singular institution for the system to operate reliably (control areas now perform this function). ${ }^{4}$

Along with more choices for the customer, other new factors will be introduced that influence the adequacy of supply and reliable operation of the system, including open access to the transmission grid, new markets for wholesale power, regional transmission groups to coordinate wholesale power transactions, and new technologies to meter electricity usage and communicate between utilities and their customers. Many of these factors are just taking shape, and their eventual form, as well as their effects on the industry, are not certain. With mandatory wholesale wheeling, the operation of the bulk power system has already become more complex.

\section{Seminal Laws}

These latest changes to the industry began with energy legislation passed in the late 1970's. The Public Utility Regulatory Policies Act of 1978 (PURPA, Public Law 95617 , which in part was intended to decrease the intensity of energy use in the United States, encouraged generation by nonutility suppliers. ${ }^{5}$ One of the effects of this law was first visible in the mid-1980's when the nonutility share of total electricity generation began to grow rapidly (Figure H1).

Subsequently, the Energy Policy Act of 1992 (EPACT, Public Law 102-486) was passed, with two major provisions that directly affect the structure of the industry: (1) the creation of a new class of electric power producers, termed exempt wholesale generators (EWGs), and (2) the broadening of the authority of the Federal Energy Regulatory Commission (FERC) to order the provision of electricity transmission services.
Together these two provisions open up the industry so that virtually any business could generate electricity and sell it at wholesale. ${ }^{6}$ The business would be guaranteed an opportunity for transmission access since FERC can now order a transmitting utility to provide transmission service, including the building of facilities needed to provide transmission, at the request of any electric utility, Federal power marketing agency, or business generating electricity for sale at wholesale. No specific levels of reliability are required by EPACT, although it does direct FERC to adhere to industry guidelines.

\section{Summary}

The reliability of service to individual customers under retail wheeling will vary based on the reliability of their supplier and the conditions of their contract. To assure the reliable operation of the bulk power system as a whole, service to some customers may be interrupted when required based on the status of their supplier and/or contract conditions.

Most State proposals for retail wheeling eliminate the requirement for electric utilities to plan for adequate generating capacity to meet demand of all consumers in their service area. Back-up service to customers of other suppliers may be based on contracts. Service to customers that want to return to the utility may be based on providing prior notification.

It appears that the reliability of the electric system can be maintained as the new structure of the industry evolves. ${ }^{8}$ Historically, the reliability criteria for the electric power industry have largely been determined by electric utilities and the North American Electric Reliability Council (NERC) and its member organizations. ${ }^{9}$ NERC and other industry organizations are committed to maintaining reliable electricity service. However, the new structure will undoubtedly make the issue of reliability more complex, particularly with a greater number and diversity of electric generating facility owners.

\footnotetext{
${ }^{4}$ Control areas consist of a utility or a group of utilities tied together by contractual arrangements that control different geographic parts of the bulk power system.

${ }^{5}$ The Supreme Court validated avoided cost pricing in 1983, which very likely had an effect on the increase in nonutility facilities.

${ }^{6}$ This had not been the case before 1992 .

"Public Law 102-486, section 211, 16 U.S.C. 824j, "The Energy Policy Act of 1992" (Enacted October 24, 1992).

${ }^{8}$ North American Electric Reliability Council, Reliability Assessment 1994-2003 (Princeton, NJ, September 1994), p. 10.

${ }^{9}$ The State Public Utility Commissions and the Federal Energy Regulatory Commission regulate electricity prices and, indirectly, affect reliability criteria.
} 
Figure H1. Nonutility Share of Total U.S. Electricity Generation, 1973-1993

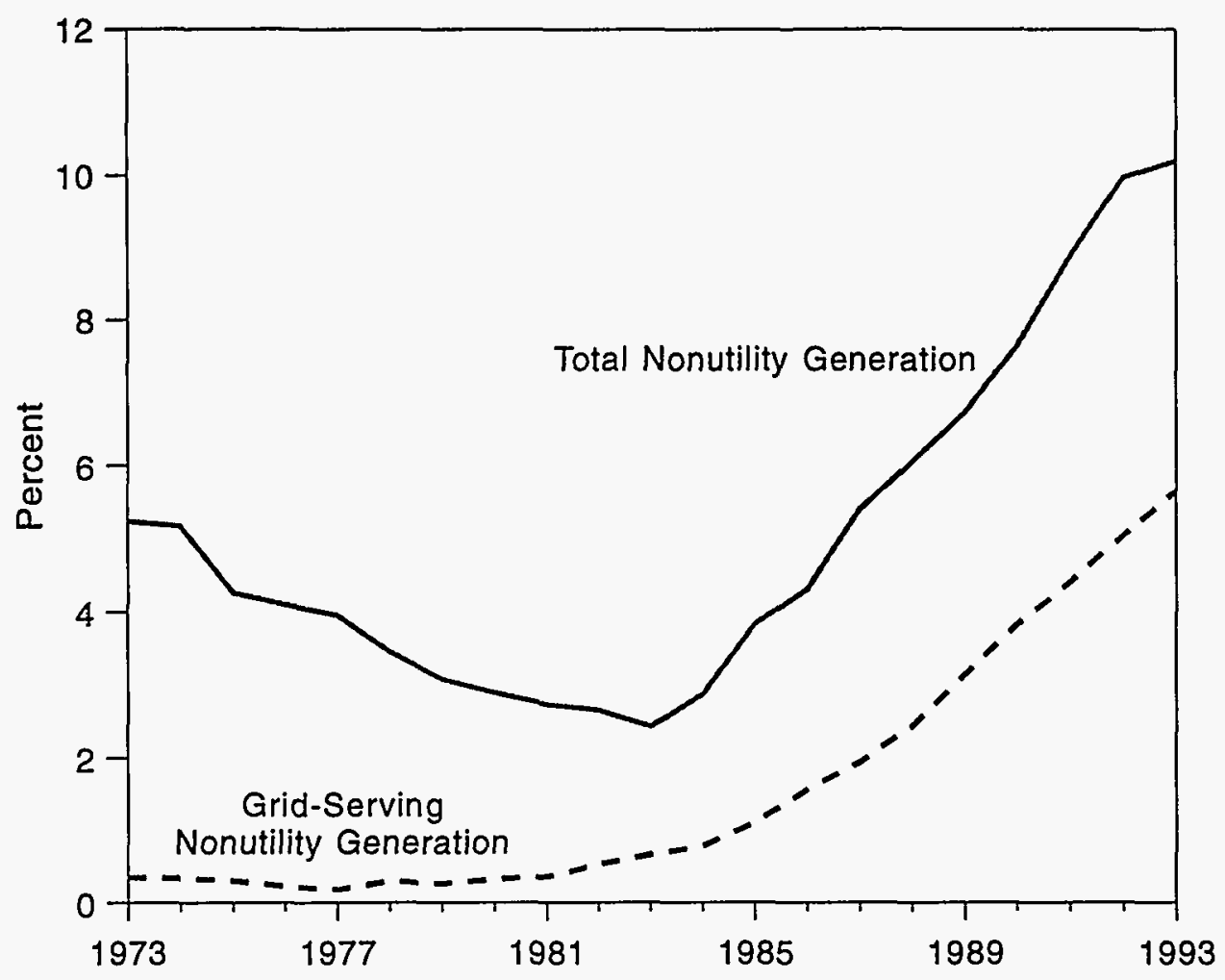

Notes: -Nonutility data for 1970 through 1979 represent capacity in the industrial sector for plants of 10 megawatts or more only. - Nonutility data for 1980 through 1984 are estimates. •Nonutility data for 1985 through 1993 include all nonutilities.

Sources: Utility Generation: 1973-1992-Energy Information Administration, Annual Energy Review 1993, DOE/EIA-0384(93) (Washington, DC, July 1994), p. 233. 1993-Energy Information Administration, Electric Power Annual 1993, DOE/EIA-0348(93) (Washington, DC, December 1994), p. 17. Nonutility Generation: Edison Electric Institute, Statistical Yearbook of the Electric Utility Industry 1993 (Washington, DC, October 1994), p. 15. 


\section{Introduction}

Extremely cold weather created record demands for electricity in the eastern two-thirds of the United States during the week of January 16, 1994. Fuel-related problems, mostly the result of transportation constraints resulting from ice accumulation on roads and waterways, and unexpected generating capacity outages at utilities and nonutilities resulted in demand not being met. Some utilities asked nonessential customers along with State governments and a portion of the Federal Government to shut down. Two electric control areas, the Pennsylvania-New Jersey-Maryland Interconnection (PJM) and Virginia Electric \& Power Company (VEPCO), instituted rolling blackouts. This disturbance was reported widely in the press and, along with other disturbances, ${ }^{1}$ peaked renewed interest in the reliability of the electric power system.

The renewed interest in reliability has coincided with substantial changes that are beginning to occur in the structure and competitiveness of the electric power industry. Juxtaposing the question of reliability and the issue of changing industry structure leads to the central concern of this report: What effect, if any, will the changing structure of the industry have on the reliability of the system?

\section{The Electric Power System and Reliability}

The electric power system is a complex combination of many different facilities. It includes electric generating plants, transmission lines, and distribution lines to customers (Figure 1). This report considers the bulk power electric system, a subsystem of the electric power system consisting of generating plants and transmission lines, but excluding distribution lines.

\section{Operation of the Bulk Power Electric System}

The major sources of electricity for the bulk power electric system are the electricity generated by utilities and nonutilities and imports of electricity from Canada or Mexico. In addition, utilities have some ability to reduce demand through direct control, load management, and interruptible power agreements.

The systems that produce and distribute electricity are different from the systems that extract and distribute other forms of energy like oil and gas. The nature of electricity is such that it follows multiple paths of least resistance from where it is produced to where it is used. It is difficult and expensive to alter that natural flow, which means that the route that electric power flows from generation to use is not entirely controllable. It is also difficult and expensive to store electricity. ${ }^{2}$ Therefore, electricity generation must be constantly controlled to meet changing demand. In other words, the demand and supply of electricity must be kept in balance across the system at all times. ${ }^{3}$ The difficulty and expense of both routing and storing electricity make operating the electric power system quite complicated.

Because utilities transmission systems are interconnected, the operation and planning of the electric power system requires careful coordination among its users. Power transfers between utility systems must be coordinated. Not only must these real-time operations be coordinated, but system planning must also be coordinated among interconnected systems to assure reliable operations.

\section{Reliability}

Reliability for an electric power system is, most simply, the extent to which consumers can obtain electricity from the system when and in the amount they want. In order to provide electricity to consumers in a reliable manner, organizations that generate and transmit electricity must be concerned with the adequacy and security of the bulk power electric system. Adequacy deals with the capacity of the system. The adequacy of the system involves the ability of its components to produce and deliver the electricity demanded by

\footnotetext{
'Energy Information Administration, Electric Power Annual 1992, DOE/EIA-0348(92) (Washington, DC, January 1994), pp. 132-140.

${ }^{2}$ Electric energy is stored indirectly as either potential energy in hydroelectric dams, and, in small applications, as chemical energy in batteries.

${ }^{3}$ For more information, see The National Regulatory Research Institute, Some Economic Principles for Pricing Wheeled Power (Columbus, OH, August 1987).
} 
Figure 1. An Electric Power System

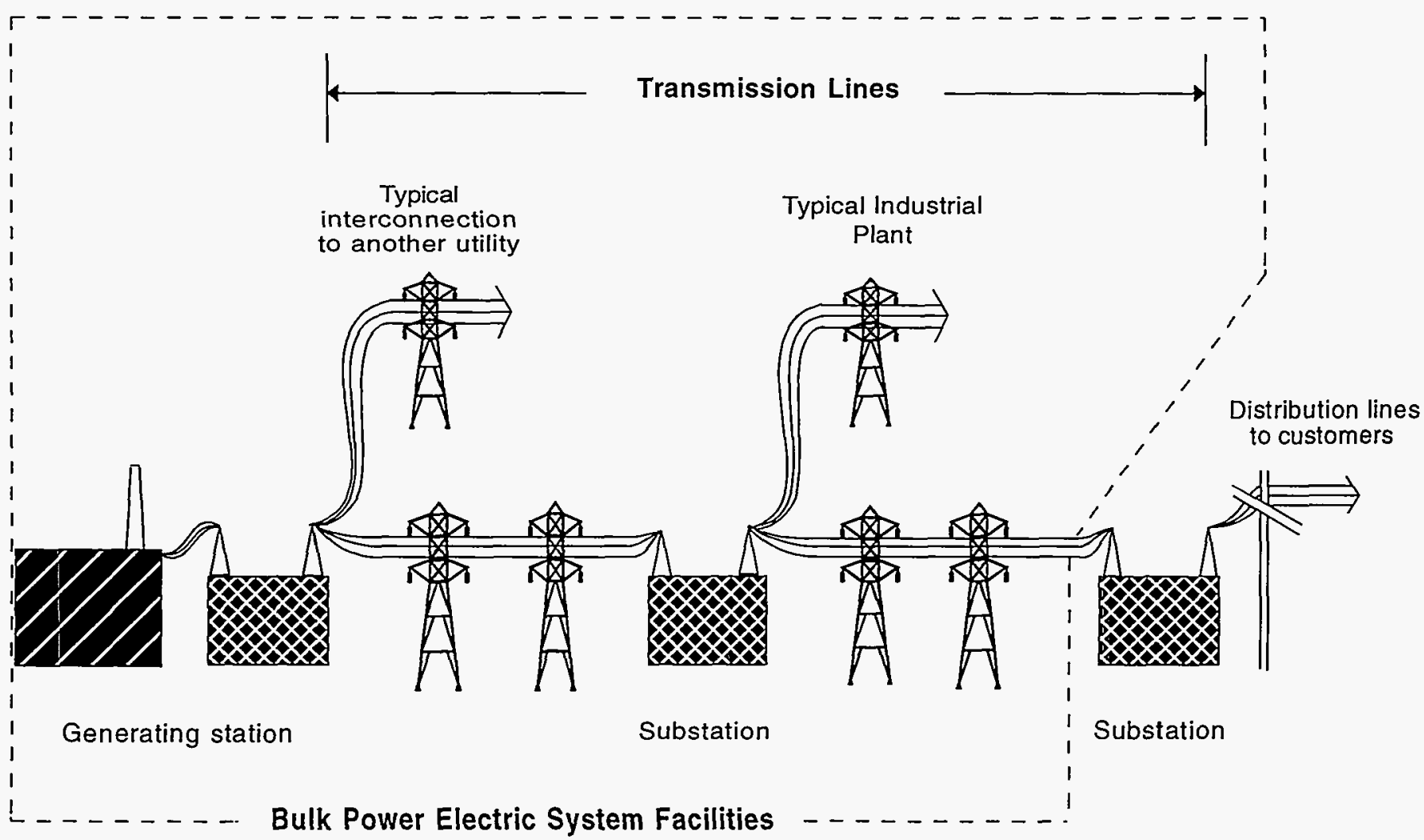

Source: North American Electric Reliability Council, Reliability Concepts (Princeton, NJ, February 1985), p. 5.

consumers-that is, is there enough generating and transmitting equipment to supply the electricity that consumers desire? Security deals with the operation of the bulk power electric system. The security of the system involves the ability of the system to survive sudden disturbances-that is, can the system recover from a failure of one of its components? ${ }^{4}$ The amount of capacity reserve margin that is required for any one utility to operate reliably depends on factors such as customer demand, equipment characteristics, and what power agreements a utility has with neighboring utilities.

This report focuses on the adequacy of electricity generating capacity for meeting demand, an issue about which there exists much data to form the basis of an evaluation. The reliable operation of the bulk electric power system is also discussed. However, the reliability of the distribution system is not addressed, since most outages in the distribution system are due to weather, e.g., trees or ice on lines, lightening, etc.

\section{The North American Electric Reliability Council}

"Coordinating, promoting and communicating about reliability" is the purpose of the North American Electric Reliability Council (NERC). It is responsible for setting and maintaining the principles, criteria, standards, and guides for planning and operating reliable bulk power electric systems. NERC was established in 1968

${ }^{4} \mathrm{NERC}$ defines reliability of the bulk power electric system as "the degree to which the performance of the elements of that system results in power being delivered to consumers within accepted standards and in the amount desired." It defines adequacy as "the ability of the ... system to supply the aggregate electric power and energy requirements of the consumers at all times ..." It defines security as "the ability of the ... system to withstand sudden disturbances ..." North American Electric Reliability Council, Reliability Concepts (Princeton, NJ, February 1985), p. 8.

${ }^{5}$ North American Electric Reliability Council, 1992 Annual Report (Princeton, NJ, 1993), p. 1. 
as a result of the Northeast Blackout, which effectively shut down the northeastern United States and much of Ontario, Canada, on November 9, 1965. Prior to the blackout, reliability of electric bulk power systems was maintained by less formal and less extensive cooperation among utilities.

A Federally sponsored investigation into the cause of the blackout uncovered that a faulty setting of a relay in Canada had resulted in tripping a 230-kilovolt line. With the loss of this line, the flow of power surged over other parallel lines in the area, overloading those lines and causing them to trip as well. While relay engineers and system operators once debated the causes of the blackout, some argue that its major causes were loading of transmission lines beyond safety limits and inadequate communication among local utilities. ${ }^{6}$

Currently, most of the electric power systems in the contiguous United States and Canada, as well as a small portion of Mexico's system located in Baja California Norte, are members of one of nine Regional Reliability Councils. These councils are the members of NERC. ' Within the contiguous United States, all electric utilities operate within one of three interconnections (Figure 2). The three major power grids or interconnections in the United States are the Eastern Interconnection, the Texas Interconnection, and the Western Interconnection. There is also a Quebec Interconnection located entirely within Canada. Utilities in each of these interconnections are continuously synchronized so that their systems operate at the same frequency.

\section{Control Areas and Power Pools}

Within the major interconnections and also within the NERC regions themselves, some utilities have formed control areas. A control area is the basic operating unit of the electric power industry. A control area can consist of either a single utility or two or more utilities tied together by contractual arrangements. Each control area manages its generation to meet electricity demand and fulfill exchange obligations. Control areas also help the entire interconnection regulate and stabilize the frequency of the electric current. The control areas are responsible for matching electricity supply with demand hour to hour and minute to minute. The coordination of the separate utility activities into an integrated power supply system is the responsibility of the control area. The operators also make sure that the transmission system is not overloaded. ${ }^{8}$ In the contiguous United States, there are more than 140 control areas. $^{9}$

Major economic benefits exist for utilities that coordinate their facilities and operations and form power pools. An electric utility must continuously balance its customers' demands for electricity with the most economical operation of its system. The utility tries to dispatch the lowest cost generating capacity available to meet changing load requirements by adjusting the mix of generating units in use or by purchasing energy in a way that does not compromise the reliability of the integrated transmission network. Often utilities can meet these requirements most economically by forming power pools.

\section{Reliability Measures}

In general, utilities are legally required to furnish adequate and reliable service to customers as a condition of their franchise. ${ }^{10}$ This means that electric generating plants and transmission lines, referred to as a bulk power system, ${ }^{11}$ are sized to meet the demand facing the system with ample reserve generating capacity to meet anticipated peak demand. The system must provide a safety margin to protect against operational and planning contingencies. Reliability is achieved through both installing parallel subsystems and being able to restore systems to normal operation

\footnotetext{
"Gregory S. Vassell, "The Northeast Blackout of 1965," Public Utilities Fortnightly (October 11, 1990), pp. 12-17.

${ }^{7}$ In recent years, a regional reliability council was formed in Alaska as an affiliate member of NERC. Data for this council are not included in the U.S. total in this report for any data sourced to NERC.

${ }^{8}$ Electricity flow through power lines is more complex than flows of petroleum products or natural gas through pipelines. Petroleum or natural gas flows are directed by controlling pumps and valves; electricity flows usually are not. Electricity flows instantaneously and takes the path of least resistance. Power is distributed across interconnected lines in inverse proportion to their impedance and will redistribute itself across the lines as their impedance changes. If overloading occurs on a line, the line will be removed from service, but the overload may then cascade to other lines. In addition, other characteristics of power flows must also be controlled in the bulk power system.

${ }^{9}$ U.S. Congress, Office of Technology Assessment, Physical Vulnerability of Electric Systems to Natural Disasters and Sabotage, OTA-E-453 (Washington, DC, June 1990), p. 32.

${ }^{10}$ Alvin Kaufman, "Electric Utilities: Overbuilt or Underbuilt," a paper presented for the National Association of Regulatory Utility Commissioners (August 6, 1988), p. 3.

"The bulk power system includes the generation and transmission network facilities of an electric system and excludes the distribution system.
} 
Figure 2. Regions and Interconnections of the North American Electric Reliability Council in the Contiguous United States

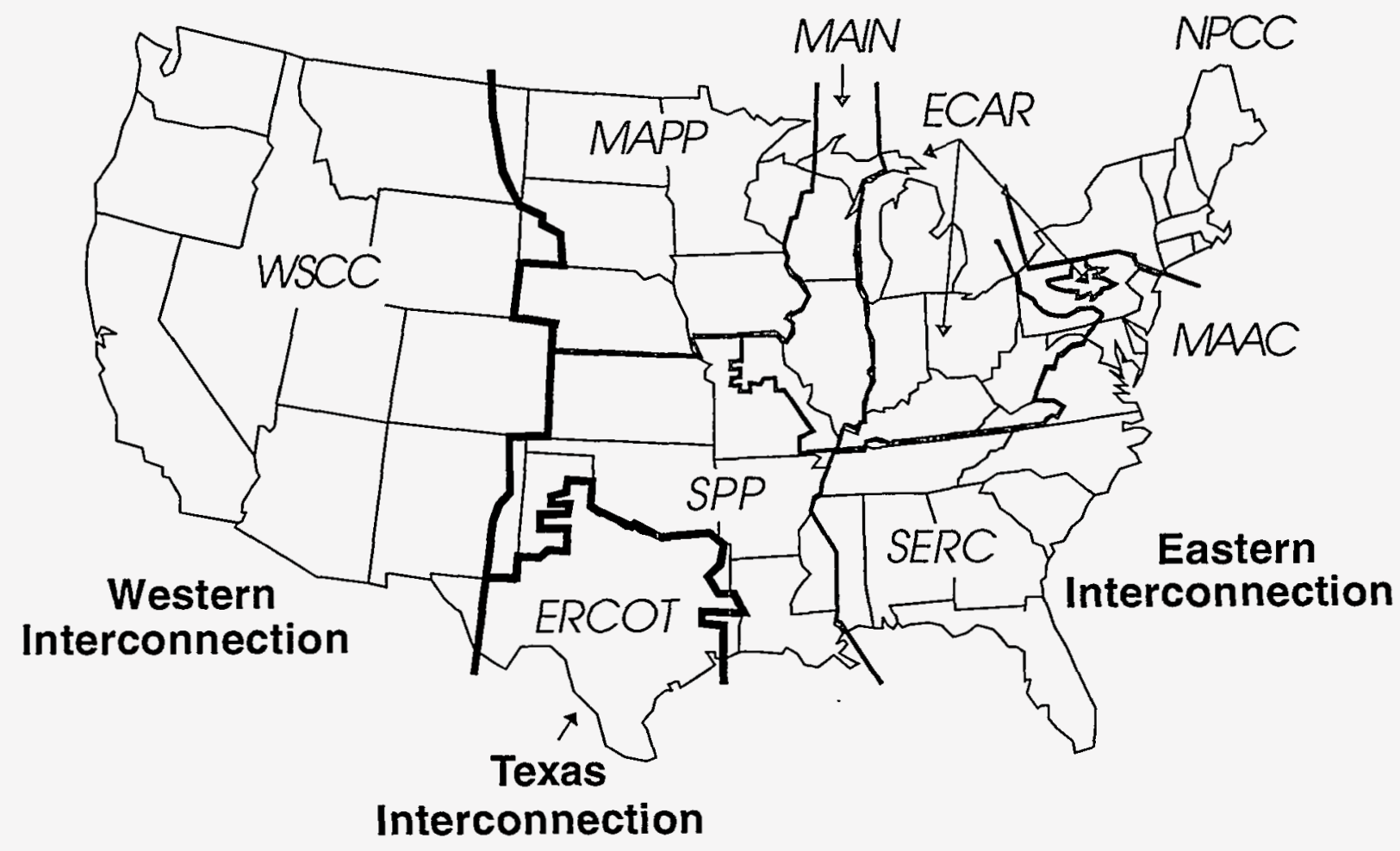

\begin{tabular}{|ll|}
\hline $\begin{array}{l}\text { North American Electric Reliability Council (NERC) Interconnections and Regions } \\
\text { Eastern Interconnection }\end{array}$ & $\begin{array}{l}\text { Texas Interconnection } \\
\text { NPCC-Northeast Power Coordinating Council }\end{array}$ \\
$\begin{array}{l}\text { MAAC-Mid-Atlantic Area Council } \\
\text { ECAR-East Central Area Reliability }\end{array}$ & Western Interconnection \\
Coordination Agreement & WSCC-Western Systems Coordinating Council \\
MAIN-Mid-America Interconnected Network & Note: NERC has one affiliate member, the Alaska Systems \\
MAPP-Mid-Continent Area Power Pool & Coordinating Council. Data from that member, as well as data \\
SPP-Southeastern Electric Reliability Council & for Hawaii that has no council, are not included in data in this \\
& report that are sourced to NERC. \\
\end{tabular}

Source: North American Electric Reliability Council.

rapidly. The amount of reserve capacity needed to assure the reliability of the system in part is dependent on the desired degree of reliability. The cost of providing reliability affects the degree of reliability provided.

Virtually all U.S. bulk power electric systems use probabilistic expectations as part of their reliability planning. The reliability criterion, that planned resources will be available to meet forecast peak demand with a specified probability, is incorporated into designing the generating and transmission capacity of the electric system.

Generally, independent assessments are made for generation adequacy and transmission reliability. Gen- 
eration adequacy is evaluated by estimating measures such as capacity margins, contingency margins, or loss of load probabilities. Transmission reliability is primarily assessed using deterministic methods. ${ }^{12}$ The bulk power systems are becoming more complex with increased purchases from nonutilities and other utilities, wheeling of power across systems, and interruptible power contracts. Due in part to these changes, the techniques for assessing reliability for planning purposes have become more quantitative.

Electric utilities are currently planning to add more than 13,000 miles of transmission lines over the next 10 years. Approximately 192,000 miles of transmission lines currently exist. ${ }^{13}$ The purpose of the transmission system is twofold: (1) to provide a path for the electricity from the supply to the demand, and (2) to connect the sources of the supply to each other. The connected system makes electricity trade possible and adds to the reliability of the entire bulk power system. For example, if a transmission line fails, the electricity flow is usually picked up by the rest of the network, with no disturbances to customers. This ability of a system to survive disturbances and maintain its stability is the part of reliability called security.

\section{Contents of the Report}

Chapter 2 of this report discusses current factors affecting the adequacy of the power system on a national and regional basis. It describes capacity margins, demand trends-including forecasts of peak demand and demand-side management demand reductions-and supply trends-such as nonutility sales to utilities and electricity trade. Finally, results of the EIA interim draft report, "Review of January 1994 Cold Wave Incidents," are summarized to indicate how the factors discussed above contributed to that electricity shortfall.

Chapter 3 reviews possible effects of expanded wholesale or retail competition on reliability of electric bulk power systems. Current research on economic considerations associated with reliability levels is also reviewed in Chapter 3.

Finally, Appendix A contains historical data for factors that have an impact on reliability. Appendix B contains a brief overview of the economics of electric power reliability.

${ }^{12}$ North American Electric Reliability Council, Reliability Concepts (Princeton, NJ, February 1985), p. 23.

${ }^{13}$ North American Electric Reliability Council, Reliability Assessment 1994-2003 (Princeton, NJ, September 1994$)$, p. 12. 



\section{Some Current Factors Considered for Adequacy of Supply}

To evaluate adequate generating capability, one of the most commonly used planning measures is capacity margins. Capacity margins indicate the amount of generating capacity in excess of peak demand available to provide backup for capacity unavailable due to scheduled maintenance, emergency outages, system operating requirements, and unforeseen electricity demand. There are many factors that affect the minimum amount of capacity margin required for reliability. These factors can be divided into two categories-demand and supply. On the demand side, forecasted peak demand and demand-side management (DSM) must be considered. As for supply, there are several factors to address, including: fuel supply, aging and modified capacity, nonutility generation, electricity trade, and compliance with the Clean Air Act Amendments of 1990 (CAAA90, Public Law 101-549). ${ }^{14}$ These factors are currently a part of what goes into planning for the economic and reliable supply of electricity.

\section{Capacity Margins}

Capacity margins are determined by subtracting projected peak demand, that has been adjusted for load management, from planned utility and nonutility supply (capacity). ${ }^{15}$ Planning for future supply adequacy requires that the supply be sufficiently higher than the projected demand to assure that demand will be expected to exceed available supply no more than a given number of times in a specified period. In projecting what capacity margin will provide the optimum level of reliability, utilities review the costs of increasing capacity margins versus the costs to customers of inadequate supply (Figure 3). Increases in the capacity margin, beyond the optimum range, will not be worth the added cost to the customer, even though increasing capacity margins translate into a reduced expectation that demand will exceed available supply.

Each NERC regional council establishes minimum reliability criteria for assessing the adequacy of their generating capacity. These criteria differ by region,
Figure 3. Variation of Customers' Costs with
Capacity Margin

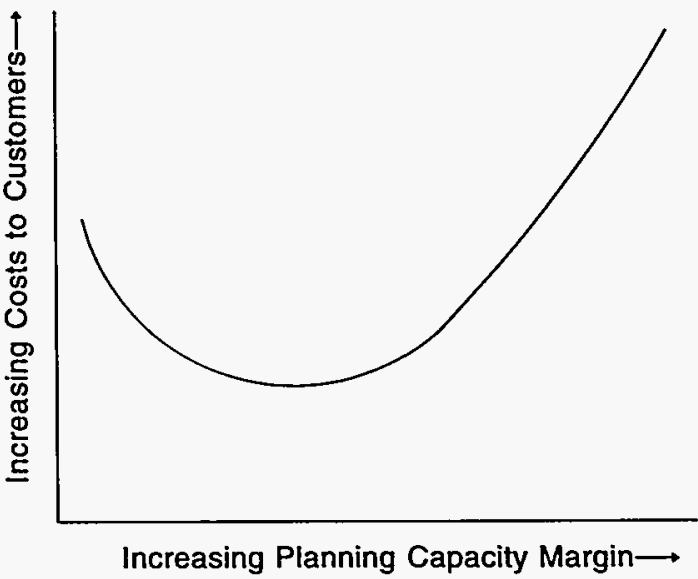

Source: North American Electric Reliability Council, Reliability Concepts (Princeton, NJ, February 1985), p. 19.

although most are within a similar range (Table 1 ). Individual utilities, power pools, and other subregional groups establish their own criteria, which may be more stringent than the regional criteria.

The aggregate U.S. capacity margin (including both utilities and the grid-serving portion of nonutilities) has shown a declining trend since 1982, from 33 percent to 21 percent in 1993. Although this drop seems dramatic, the decline must be viewed in its historical context. In the 1970's, the forecasted peak demand was much larger than the peak demand that actually occurred. Therefore, utilities had planned and built more capacity than was actually needed by the time the capacity was completed. This caused quite high capacity margins. These high margins were not necessary for the level of reliability deemed acceptable and in recent years margins have been declining towards more efficient levels.

Regional capacity margins are currently projected to continue to decline to between 11 and 20 percent by

${ }^{14}$ See Appendix A for detailed data of these factors.

${ }^{15}$ See Appendix A for a detailed definition of capacity margins. 
Table 1. NERC Regional Criteria for Assessing Adequacy of Generating Capacity

\begin{tabular}{|c|c|}
\hline Region & Published Criterion \\
\hline $\begin{array}{l}\text { ECAR } \\
\text { (East Central Area Reliability } \\
\text { Coordination Agreement) }\end{array}$ & $\begin{array}{l}\text { For the Region: } \\
1 \text { to } 10 \text { days/year Dependence on } \\
\text { Supplemental Capacity Resources }\end{array}$ \\
\hline $\begin{array}{l}\text { ERCOT } \\
\text { (Electric Reliability Council } \\
\text { of Texas) }\end{array}$ & $\begin{array}{l}\text { Each Member System: } \\
\text { At least } 15 \text { percent Reserve Margin }\end{array}$ \\
\hline $\begin{array}{l}\text { MAAC } \\
\text { (Mid-Atlantic Area Council) }\end{array}$ & $\begin{array}{l}\text { For the Region: } \\
1 \text { day in 10-year LOLP } \\
\text { Each Subregion: } \\
1 \text { day in 10-year LOLP }\end{array}$ \\
\hline $\begin{array}{l}\text { MAIN } \\
\text { (Mid-America Interconnected } \\
\text { Network) }\end{array}$ & $\begin{array}{l}\text { For the Region: } \\
1 \text { day in } 10 \text {-year LOLP }\end{array}$ \\
\hline $\begin{array}{l}\text { MAPP } \\
\text { (Mid-Continent Area Power } \\
\text { Pool) }\end{array}$ & $\begin{array}{c}\text { Each Member System: } \\
15 \text { percent Reserve Margin }{ }^{\mathrm{a}} \text { (10 } \\
\text { percent for Hydro Systems) }\end{array}$ \\
\hline $\begin{array}{l}\text { NPCC } \\
\text { (Northeast Power } \\
\text { Coordinating Council) }\end{array}$ & $\begin{array}{c}\text { Each Subregion: } \\
\text { Once in 10-year customer } \\
\text { disconnection }\end{array}$ \\
\hline $\begin{array}{l}\text { SERC } \\
\text { (Southeastem Electric } \\
\text { Reliability Council) } \\
\end{array}$ & $\begin{array}{c}\text { Each Member System has own } \\
\text { criteria }\end{array}$ \\
\hline $\begin{array}{l}\text { SPP } \\
\text { (Southwest Power Pool) }\end{array}$ & $\begin{array}{c}\text { For the Region: } \\
\text { 16.7 percent Capacity Margin } \\
\text { Each Member System: } \\
15.25 \text { percent Capacity Margin }{ }^{\mathrm{a}} \text { or } 1 \\
\text { day in 10-year LOLP (Floor of } 9 \\
\text { percent for Hydro Systems; } 13 \\
\text { percent for Steam Systems) }\end{array}$ \\
\hline $\begin{array}{l}\text { WScC } \\
\text { Western Systems } \\
\text { Coordinating Council) }\end{array}$ & $\begin{array}{l}\text { Choice of criteria based on amount of } \\
\text { hydro and non-hydro capability, } \\
\text { considering scheduled maintenance } \\
\text { and load responsibility, or annual } \\
\text { criterion based on the probability of } \\
\text { loss of load. }\end{array}$ \\
\hline
\end{tabular}

${ }^{a}$ For an explanation of reserve margins and capacity margins, see box on page 30.

LOLP $=$ Loss of Load Probability.

NERC = North American Electric Reliability Council.

Note: LOLP is a measure of the expectation that system demand will exceed capacity during a given period.

Source: North American Electric Reliability Council, NERC Report of Regional Criteria and Guides for Planning Reliable Bulk Electric Systems (Princeton, NJ, November 1994), pp. 9 and 20.
2003. The change is represented by movement from a point at the upper right of the reliability cost curve toward the bottom of the curve (Figure 3 ).

\section{Demand}

\section{Forecasts of Peak Demand}

Forecasts of peak demand are important in planning for an adequate electricity supply. These projections indicate how much electricity will be needed, thereby translating into how much capacity will be needed. Peak demand is difficult to forecast because it is affected by many factors, including weather and the economy. The projections for peak demand typically represent a level at which there is a 50/50 chance of either exceeding the projections or being below the projected value. In forecasting peak demand, both load management and interruptible demands are taken into consideration, as well as conservation, energy efficiency, and other indirect DSM programs. When these are subtracted from peak demand, the result is the net peak demand, which is usually used by utilities in planning for their capacity needs. ${ }^{16}$ From 1983 through 1993, peak demand has usually been underestimated, but the magnitude of the difference from the actual is less than the prior 10 years. (See Demand Trends in Appendix A.)

Peak demand in the United States overall occurs in the summer; however, peak demands in individual regions and individual utilities can occur at different times. The U.S. peak demand is the noncoincidental sum of the individual regional peak demands, which are (usually) the sum of the noncoincidental utility peak demands.

The peak demand in the United States has shown an average annual growth rate of 2.5 percent over the last 10 years, 1983 through 1993. Peak demand for the next 10 years, 1993 through 2003, is currently projected to have a slightly lower growth rate of 1.7 percent.

\section{Demand-Side Management}

An important factor to consider currently when planning for an adequate electricity supply is DSM. DSM is defined as the planning, implementation, and monitoring of utility activities designed to influence customer use of electricity in ways that will produce desired changes in load shape. ${ }^{17}$

\footnotetext{
${ }^{16}$ North American Electric Reliability Council, 1990 Electricity Supply E Demand (Princeton, NJ, November 1990), pp. 8-9.

${ }^{17}$ Load shape refers to the shape of the load curve, i.e., the graph of the hourly loads on a system.
} 
The most common objectives of DSM programs are energy conservation, peak clipping, load-shifting, and valley-filling. Over the past decade, DSM has come to be considered a viable business strategy and is recognized by the electric utility industry as an alternative to building more capacity that may or may not turn out to be the most economic alternative. In 1993, energy savings and peakload reductions resulting from DSM programs were reported by 971 electric utilities. Energy efficiency programs accounted for 45 percent of actual peakload reductions (i.e., the installed load reduction capability). Energy savings increased from 36.2 billion kilowatthours in 1992 to 44.3 billion kilowatthours in 1993. Ninety-one percent of energy savings resulted from energy efficiency programs. Total expenditures on electric utility DSM programs were approximately $\$ 2.8$ billion in 1993 , and this figure is expected to increase significantly during the $1990^{\prime} \mathrm{s} .{ }^{18}$ The Energy Information Administration (EIA) is currently compiling information on State Public Utility Commission efforts to evaluate DSM. The findings will be included in a report that is planned for publication in 1995.

Between 1993 and 1998, energy savings are projected to increase at an average annual rate of 15 percent to 90.1 billion kilowatthours, potential peakload reductions are expected to increase at an average annual rate of 4 percent to 32.7 gigawatts, and utility costs are projected to increase to $\$ 3.9$ billion in $1998 .{ }^{19}$ However, the projected DSM savings in the future are more uncertain now due to the likelihood of increased competition.

\section{Supply}

\section{Increasing Use of Natural Gas for Generation}

At the end of 1993, utilities planned to build 28 new gas steam units and 250 gas-fired combustion turbines with a total net summer capability of 24.4 gigawatts by 2003. This represents 62 percent of the utility planned additions..$^{20}$ Natural gas has also increasingly been the major fuel used by nonutility electricity generators. In 1993, natural gas fueled more than half of all nonutility electric generation, ${ }^{21}$ and gas consumption has been climbing steadily for several years (Figure 4).
Figure 4. Natural Gas Consumption for Electricity Production, 1989-1993

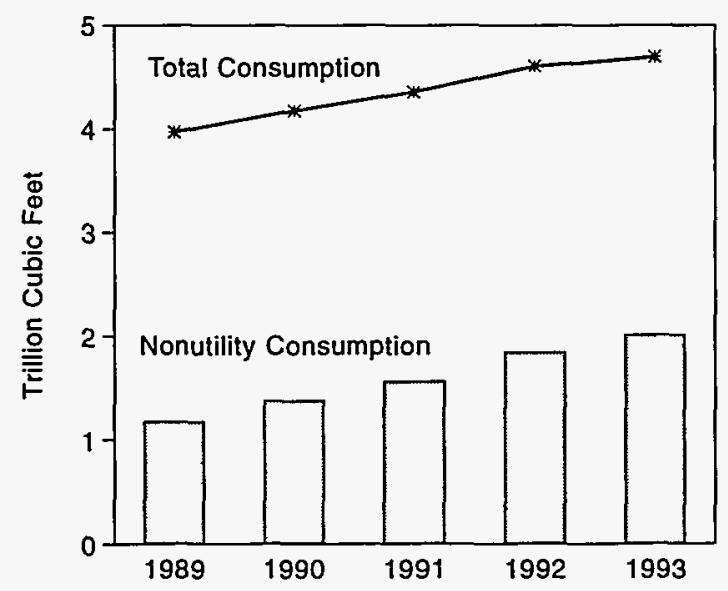

Source: Utility Data: Energy Information Administration, Electric Power Annual, DOE/EIA-0348 (Washington, DC, 19921994). Nonutility Data: Energy Information Administration, Form EIA-867, “Annual Nonutility Power Producer Report."

With the.increasing use of natural gas for electricity production, there is concern about gas delivery reliability problems that can occur, particularly during periods of extreme cold weather. In particular, interruptible gas sales can be shut off to utilities and nonutilities during cold weather to allow supply to population centers for heating homes and businesses. The interruption of natural gas for generation could have an effect on generation. Many gas-fired units can also be fired with oil; however, oil may not always be available.

\section{Aging and Modified Capacity}

At the end of 1993, fossil-fueled steam capability accounted for 72 percent of U.S. electric utility net summer generating capability; however, by the year 2003 , large amounts of steam-electric capacity will have reached or exceeded 30 years of age. By 2003, the average age of the Nation's coal-fired units (weighted by nameplate capacity) will be 32 years, and the average age of oil-/gas-fired units will be 36 years. Nuclear plants are somewhat younger, with an average age of 23 years in $2003 .^{22}$

\footnotetext{
${ }^{18}$ Energy Information Administration, Electric Power Annual 1993, DOE/EIA-0348(93) (Washington, DC, December 1994), p. 11.

${ }^{19}$ Energy Information Administration, Electric Power Annual 1993, DOE/EIA-0348(93) (Washington, DC, December 1994), pp. 112-113.

${ }^{20}$ Energy Information Administration, Inventory of Power Plants in the United States 1993, DOE/EIA-0095(93) (Washington, DC, December 1994), Tables 1 and 4.

${ }^{21}$ Edison Electric Institute, 1993 Capacity and Generation of Non-Utility Sources of Energy (Washington, DC, November 1994$)$, p. 52.

2Energy Information Administration, Form EIA-860, "Annual Electric Generator Report" (1993).
} 
Two methods for maintaining generating capacity online or adding generating capacity to a utility system are plant betterment and repowering. These options are frequently measured in terms of improved availability, reduced-outage rates, avoided new capacity, and the improved efficiency of aging units. Average generating unit availability has shown a slight upward trend over the past several years, while forced-outage rates for fossil-fueled units are presently down several percentage points. ${ }^{23}$ In most cases repowering results in an increase in net dependable capability and in reduced emissions. Plant betterment and repowering are key strategic planning issues in the 1990's that could result in improved generation availability for existing units.

\section{Nonutility Generation}

Nonutility generation began increasing in the mid1980 's. In 1979, electric utilities supplied 97 percent of the electricity generated in the United States. ${ }^{24}$ The balance was produced by nonutilities. The passage of the Public Utility Regulatory Policies Act (PURPA, Public Law 95-617) in 1978 encouraged the construction of new nonutility facilities by providing a market for their power. By 1993, the electric utility share of generation declined to 90 percent (Figure 5). New legislation, the Energy Policy Act of 1992 (EPACT, Public Law 102486), was designed to bring even more competition into the market place. EPACT created a new category of electricity producer, the exempt wholesale generator, removing impediments to development contained in the Public Utility Holding Company Act of 1935 (PUHCA, Public Law 74-333). It also guaranteed access to transmission lines for wholesale generators.

Some State Public Utility Commissions are now proposing even broader competition for the retail market, not just the wholesale market. Evolution of electricity markets toward a more competitive structure in the 1990's could have a major impact on future electricity reliability planning and raise questions about responsibility for reliable service. To help address these issues, the NERC Board of Trustees now has two nonutility members and an observer from a nonutility trade association. In addition, the NERC regional reliability councils have opened membership to nonutilities that comply with NERC reliability standards, just as utilities comply. Some nonutilities have already joined regional councils, and membership changes have been made to get all of the industry participating.
Figure 5. Nonutility Share of Total U.S. Electricity Generation, 1973-1993

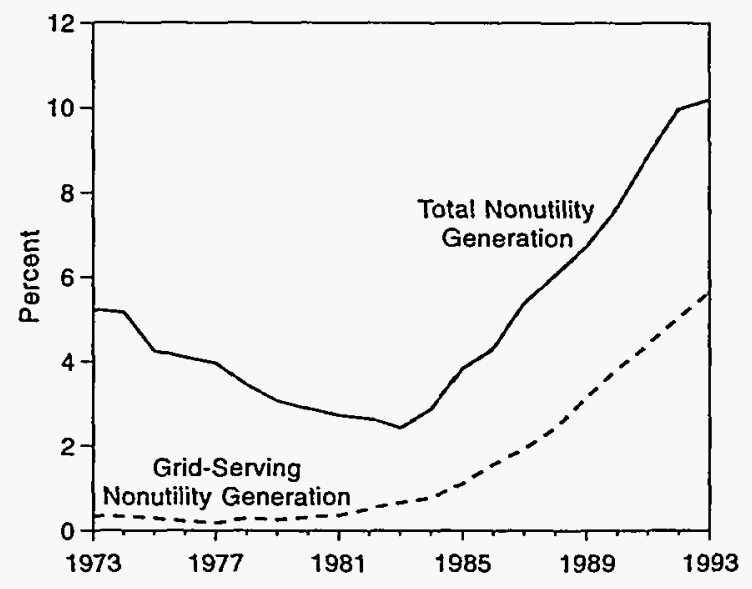

Notes: -Nonutility data for 1970 through 1979 represent capacity in the industrial sector for plants of 10 megawatts or more only. -Nonutility data for 1980 through 1984 are estimates. Nonutility data for 1985 through 1993 include all nonutilities.

Sources: Utility Generation: 1973-1992-Energy Information Administration, Annual Energy Review 1993, DOE/EIA0384(93) (Washington, DC, July 1994), p. 233. 1993-Energy Information Administration, Electric Power Annual 1993, DOE/EIA-0348(93) (Washington, DC, December 1994), p. 17. Nonutility Generation: Edison Electric Institute, Statistical Yearbook of the Electric Utility Industry/1993(Washington, DC, October 1994), p. 15.

NERC also published a report in 1992 concerning reliability issues related to integrating nonutility facilities into the bulk power system..$^{25}$ Three fundamental issues that need to be addressed were identified in the report: (1) a nonutility operating within a utility's system is not usually under the operating control of that utility; (2) utilities and nonutilities do not always have the same motives and obligations; and (3) nonutilities may not be able to supply the purchasing utility with a long-term capacity resource. Each of these issues needs to be resolved as nonutilities continue to grow within the electric power system.

\section{Electricity Trade}

Trade between electricity suppliers enhances reliability by providing the opportunity for supply from outside

\footnotetext{
${ }^{23}$ North American Electric Reliability Council, Reliability Assessment 1994-2003 (Princeton, NJ, September 1994$)$, p. 16.

${ }^{24}$ Energy Information Administration, The Changing Structure of the Electric Power Industry 1970-1992, DOE/EIA-0562 (Washington, DC, March 1993), p. 7.

${ }^{25}$ North American Electric Reliability Council, Integrating Non-Utility Generators (Princeton, NJ, January 1992), pp. 9-10.
} 
a utility's system. There are two main types of electricity trade-firm and nonfirm. Firm sales usually involve the sale of capacity and are included in the planning for supply adequacy. Utilities typically engage in nonfirm sales to gain operational savings. ${ }^{26}$ Emergency assistance is also possible, and if a problem occurs in one system, electricity supplied from a nearby system can meet demand without an interruption to customers. Electricity trade also allows a system to operate more economically by purchasing electricity that is cheaper than its production costs.

Essentially all electricity trade occurs within the three major interconnections in the United States. Bulk power trade among the interconnections is minimal when compared with trade within each interconnection. To assure reliable operations, electricity trade requires communication and coordination of the transmission system. As trade and the number of participants increase, better communication and coordination will be necessary.

Another issue is international electricity trade. U.S. utilities purchase and sell electricity from and to Canadian and Mexican utilities. The purchases, however, are a small part of total electricity consumption overall in the United States. This trade includes both firm power purchases and interruptible purchases. It also includes exchanges of power with Canada since Canada typically uses more electricity in the winter while the United States uses more electricity in the summer. International trade can be useful for reliability as it offers another source of electricity.

\section{Clean Air Act Amendments of 1990}

To comply with Phase I of CAAA90, 261 affected generating units must reduce sulfur dioxide $\left(\mathrm{SO}_{2}\right)$ and nitrogen oxides $\left(\mathrm{NO}_{\mathbf{x}}\right)$ emissions beginning in 1995. For $\mathrm{SO}_{2}$ reductions, about 62 percent plan to switch, blend, or co-fire with a lower sulfur fuel to reduce their emissions. By switching to a lower sulfur fuel, the unit (in some cases) will be derated, that is, reduce its generating capacity. Also, about 10 percent have decided to install flue gas desulfurization (FGD) systems which remove $\mathrm{SO}_{2}$ from the boiler flue gas. FGD systems reduce the generator's output by approximately 2 per- cent as electricity is required to run the FGD system. Both of these options reduce the output of the generators and must be taken into account in determining capacity margin for generation. ${ }^{27}$ FGD equipment may also degrade unit availability and thus negatively impact system reliability. Phase II, which begins in 2000 , will require additional plant modifications.

\section{Recent Experience}

\section{Electric System Disturbances in the United States}

"The reliability of the U.S. electric power systems has been so high that the rare occurrences of major blackouts have been prominent national and even international news items. ${ }^{\prime 28}$ Even though disturbances to the system do occur, the United States has one of the most reliable systems in the world. ${ }^{29}$ Industry reliability has been developed over years of supply-side efforts when the primary objective was increasing its capability to serve.

Nearly half (48 percent) of the 52 reported disturbances to the U.S. electric system in 1993 were caused by natural occurrences, such as weather (Figure 6). The damage caused by these events was mostly confined to transmission and distribution facilities, although some generating plants were also affected. Planning and design efforts only minimally mitigate the effects of these disturbances. ${ }^{30}$

Many of the other causes of outages or unusual events also occurred within transmission and distribution systems. Line faults and outages along with equipment problems such as circuit breaker failure accounted for 27 percent. Vandalism and sabotage to the transmission or distribution system caused 3 disturbances in 1993, and fire caused another 3 disturbances.

Most of the remaining problems were related to the generating system. Two instances of coal shortages were reported. The cause of the shortages was related to a coal strike and flooding in the Midwest which

\section{7.}

${ }^{26}$ Energy Information Administration, Electric Trade in the United States 1992, DOE/ELA-0531(92) (Washington, DC, September 1994), p.

${ }^{27}$ Energy Information Administration, Electric Utility Phase I: Acid Rain Compliance Strategies for the Clean Air Act Amendments of 1990, DOE/EIA-0582 (Washington DC, March 1994).

${ }^{28}$ Congress of the United States, Office of Technology Assessment, "Physical Vuinerability of Electric Systems to Natural Disasters and Sabotage," OTA-E-453 (Washington, DC, June 1990), p. 1.

${ }^{29}$ North American Electric Reliability Council, NERC 2000 (Princeton, NJ, September 30, 1993), p.2.

${ }^{30}$ Data and information concerning the electric system disturbances are from the Energy Information Administration, Electric Power Annual 1993, DOE/EIA-0348(93) (Washington, DC, December 1994), pp. 133-139. 
Figure 6. Percent of Major U.S. Electric System Disturbances and Unusual Occurrences by Cause of Outage, 1993

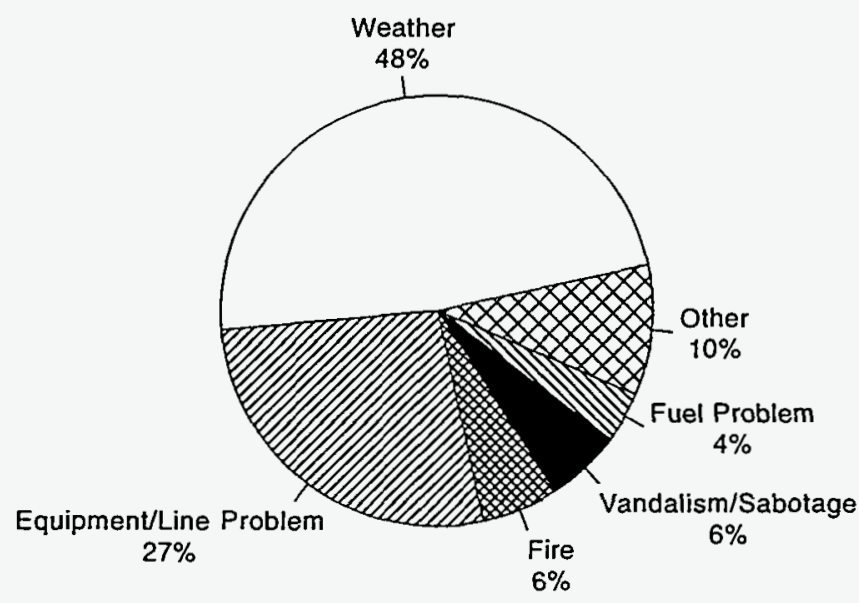

Note: "Other" includes a voltage reduction test, an accident, fallen trees, high load, and operation disturbances.

Source: Energy Information Administration, Electric Power Annual 1993, DOE/EIA-0348(93) (Washington, DC, December 1994), pp. 133-139.

delayed shipment. One incident of a tripped line caused two generating units to go off-line, dropping 1,680 megawatts. A voltage reduction test affected customers in New York, and high temperatures caused high load in Missouri.

Because electric systems are highly interconnected, electric system disturbances have reliability implications beyond the utility system in which the disturbance occurs. A disturbance may readily spread beyond the boundaries of the system in which it originates. Coordinated planning of protective relaying by utilities and coordinated operation can reduce the extent to which a disturbance is propagated and minimize the time needed to restore service. NERC criteria and guides for interconnected systems operations were developed to address these issues.

\section{A Look at Winter 1994}

During an unusual event, available generating capacity is affected by many different factors, including those noted in this chapter. Because the reliability of an electric power system depends upon how the system reacts in unusual situations, this section highlights one recent, very unusual event-the cold wave of winter
1994. Factors such as nonutility power, DSM, and electricity trade all played a part in meeting demand during this event.

Before looking at details of the event, it is important to note that, although high capacity margins were projected for the affected area, demand still could not be met. Factors such as unscheduled outages coupled with increased demand, both caused by the cold weather, left no available capacity. The NERC report on the cold wave of January 1994 stated that, "equipment problems and extreme weather in any Region, however, can combine to strain margins even when the projected margins are adequate. ${ }^{\prime \prime 1}$ In unusual situations such as these, projected capacity margins may not be useful.

In general, no single percentage of capacity margin is appropriate for all utilities and/or control areas. The percentage depends on factors such as the duration and size of demand, equipment characteristics, and energy sources, including prime mover type and size of generating plants. Energy sources include utility-owned generating capacity, power purchases from other electric utilities, nonutility generators, imports from Canada and Mexico, and load reduction through DSM. Outages for scheduled maintenance and refueling (in the case of nuclear units) must be planned to minimize their impact on the capacity margin that is held in reserve for unplanned outages and uncertainty in demand.

\section{Facts of the Event}

The cold weather of January 1994 was unusual because of the extremely low temperatures and the breadth of the geographic area, the Mid-Atlantic States and the Northeast, simultaneously subjected to the cold. It created record high electrical demands and caused fuelrelated problems and mechanical failures resulting in unexpected generating capacity outages. The electric utility system in the eastern two-thirds of the United States was strained to the point that demand could not be met, as many utilities experienced their winter peak demand at the same time (Table 2 and Figure 7). Voltage reductions were instituted in many regions and public appeals were issued to conserve energy.

As the electric supply situation continued to deteriorate, some utilities asked nonessential commercial and industrial customers along with State governments and a portion of the Federal Government to shut down. Rolling blackouts were required in the Pennsylvania-New Jersey-Maryland Interconnection (PJM) and Virginia

\footnotetext{
${ }^{31}$ North American Electric Reliability Council, Report on Electric Utilities' Response to the Cold Wave of January 1994, Report by the Blue Ribbon Task Force to the NERC Board of Trustees (Princeton, NJ, April 11, 1994), p. 4.
} 
Electric \& Power Company (VEPCO) control areas to maintain a balance between available capacity and demand. The utility industry followed emergency response procedures and guidelines, and major power disruptions were prevented.

PJM and VEPCO were the two control areas that were forced to take the most severe actions to prevent major power disruptions. ${ }^{32}$ PJM forecast a winter capacity margin of more than 26 percent; however, peakload was 2,000 megawatts more than planned (Table 3 and Figure 8). Peakload would have been even larger if PJM had not implemented load reduction techniques. DSM programs that could be implemented, such as direct load control and interruptible load, reduced load by about 1,000 megawatts. Voltage reductions reduced load by another 600 megawatts. Additional load was reduced through public appeals and interruption of firm load.

PJM had almost 19 gigawatts of capacity unavailable-approximately 5 gigawatts of scheduled outages and almost 14 gigawatts of unscheduled utility and nonutility outages-and could not meet demand. The majority of the unplanned outages were due to fuelrelated and equipment failure problems, 35 percent and 48 percent, respectively. ${ }^{33}$ Fuel availability was interrupted due to delivery problems caused by icy roads and rivers, frozen coal and loading docks, and a loss of natural gas interruptible supply because of increased heating needs. Equipment problems occurred mainly at coal plants from frozen conveyor belts and frozen mine equipment, as well as derating of scrubber and precipitators that were affected by the cold weather. Generators operated by nonutilities were facing similar cold-weather-related problems.

VEPCO confronted a new all-time peak demand and experienced a situation similar to PJM. The control areas were faced with a number of problems including high unplanned outages of owned and nonutility capacity, communications difficulties, and power transfer capability from neighboring control areas that was loaded to reliability limits.

PJM and VEPCO implemented emergency operating procedures when it was determined that power pur- chases from other systems, although more than six times higher than projected, would be inadequate to meet demand. The emergency procedures implemented by these control areas included voluntary conservation appeals, interruptible customers shutdowns, other DSM measures, voltage reductions, and rolling blackouts. Appeals were also made by PJM to close down all nonessential facilities.

\section{Evaluation of the Event}

EIA initiated a comprehensive study of these events. ${ }^{34}$ In the study no one single problem was identified as causing the supply shortages, and no one solution was found to prevent or mitigate the severe actions that utilities had to take to prevent uncontrolled outages. A variety of observations and recommendations were made that might improve the response and lessen the impacts on customers in similar future circumstances. But even resolution of the identified issues does not guarantee power availability in the future.

One of the challenges facing the industry is to evaluate the January cold wave utility response in the context of the industry's evolving structure. The crisis highlighted one of the changes that is occurring in the structure and operations of the utility industry - an increased dependence on nonutility power.

Nonutilities provide a substantial portion of supply in some areas. More than 50 percent of nonutility capacity was available during the winter 1994 cold wave period, according to PJM, compared with 74 percent of utility capacity. Many nonutility-owned units were subject to the same extreme conditions and experienced many of the same operating, fuel handling and fuel delivery problems as the utility-owned units. In the Commonwealth of Virginia, 84 percent of the net dependable capacity owned by VEPCO was available and on-line on January 19, while 62 percent of the capacity owned by the independent power producers was available. A recent industry-wide survey of nonutility plants in the United States found that they have high average availability. The nonutility plants reported an average availability of 93.4 percent for combined-cycle facilities and 90 percent for solid-fuel plants, according to the study, "Operational Experience in Competitive Electric

${ }^{32}$ The PJM power pool (also a control area) consists of 11 member utilities, 76 other utilities, and 538 operating units, and it serves an estimated 22 million people in a 50,000 square mile area of Pennsylvania, New Jersey, Maryland, Delaware, the District of Columbia, and a portion of Virginia. For planning purposes, the Virginia Electric \& Power Company (VEPCO) area also includes several small municipal and cooperative utilities. However, VEPCO alone serves about 1.8 million customers in Virginia and 20 counties in North Carolina-a franchise area covering approximately a 30,000 square mile area.

${ }^{33}$ North American Electric Reliability Council, Report on Electric Utilities' Response to the Cold Wave of January 1994, Report by the Blue Ribbon Task Force to the NERC Board of Trustees (Princeton, NJ, April 11, 1994), p. 6.

${ }^{34}$ Energy Information Administration, "Review of January 1994 Cold Wave Incidents," Interim Draft Report (Washington, DC, June 24, 1994). 
Generation." The study also indicated that nearly half of all plant managers believe that their facilities were not designed with adequate winterization protection. Retrofits were often needed to install electric and steam heat tracing of exposed pipe, to enclose small tanks and pumps, to cover fuel storage areas and to cover fuel and ash conveyor systems. ${ }^{35}$

Along with purchases of nonutility generation, utilities depended on DSM programs to control load during the crisis. PJM was able to achieve more savings than planned from direct load control, but 24.5 percent less than planned from its interruptible demand programs. Understanding the future impacts of factors such as nonutilities and DSM is a difficult but important area for the industry to pursue. Also, new factors must now be considered, including the restructuring of the industry, generation deregulation, open transmission access, and the potential evolution of an electricity commodities market on utility operations during crises and ultimately on responsibilities to serve.

Table 2. Selected Winter Peak Demand Records, Week Ending January 22, 1994 (Megawatts)

\begin{tabular}{|c|c|c|c|}
\hline Utility & Peak Demand & Utility & Peak \\
\hline 1 - Allegheny Power System (a) & 7,153 & 21 - Indianapolis Power \& Light Company & 2,543 \\
\hline 2 - American Electric Power System (b) & 19,236 & 22 - Kentucky Utilities Company & 3,092 \\
\hline 3 - Atlantic City Electric Company & 1,510 & 23 - Long Island Lighting Company & 3,001 \\
\hline 4 - Baltimore Gas \& Electric Company & 6,038 & 24 - New England Electric System (d) & 4,121 \\
\hline 5 - Boston Edison Company & 2,473 & 25 - New York State Electric \& Gas Corporation & 2,618 \\
\hline 6 - Carolina Power \& Light Company & 10,129 & 26 - Niagara Mohawk Power Corporation & 6,408 \\
\hline 7 - Central Hudson Gas \& Electric Company & 840 & 27 - Northeast Utilities (e) & 6,271 \\
\hline 8 - Central Illinois Public Service Company & 1,989 & 28 - Northern Indiana Public Service Company & 2,154 \\
\hline 9 - Cincinnati Gas \& Electric Company & 4,077 & 29 - Ohio Edison \& Pennsylvania Power Companies & 5,098 \\
\hline 10 - Cleveland Electric Illuminating Company & 3,233 & 30 - Pennsylvania Power \& Light Company & 6,403 \\
\hline 11 - Commonwealth Edison Company & 14,179 & 31 - Philadelphia Electric Company & 5,957 \\
\hline 12 - Consolidated Edison Company of New York & 7,787 & 32 - Potomac Electric Power Company & 5,010 \\
\hline 13 - Consumers Power Company & 5,496 & 33 - South Carolina Electric \& Gas Company & 3,444 \\
\hline 14 - Dayton Power \& Light Company & 2,747 & 34 - Southem Company System (f) & 24,545 \\
\hline 15 - Delmarva Power \& Light Company & 2,525 & 35 - St. Joseph Light \& Power Company & 276 \\
\hline 16 - Detroit Edison Company & 7,264 & 36 - Tennessee Valley Authority & 24,723 \\
\hline 17 - Duke Power Company & 16,630 & 37 - Toledo Edison Company & 1,471 \\
\hline 18 - Eastern Utilities Associates (c) & 794 & 38 - Virginia Electric \& Power Company & 14,877 \\
\hline 19- Empire District Electric Company & 670 & 39 - Wisconsin Public Service Corporation & 1,668 \\
\hline 20 - Illinois Power Company & 3,115 & & \\
\hline
\end{tabular}

(a) Includes Monongahela Power Company, Potomac Edison Company, and West Penn Power Company.

(b) Includes Appalachian Power Company, Indiana Michigan Power Company, Kentucky Power Company, Kingsport Power Company, and Wheeling Power Company.

(c) Includes Eastern Edison Company, Montaup Electric Company, and Newport Electric Company.

(d) Includes Granite State Electric Company, Massachusetts Electric Company, Narragansett Electric Company, and New England Power Company.

(e) Includes Connecticut Light \& Power Company, Public Service Company of New Hampshire, and Western Massachusetts Electric Company.

(f) Includes Alabama Power Company, Georgia Power Company, Gulf Power Company, Mississippi Power Company, and Savannah Electric Power Company.

Source: Edison Electric Institute, special telephone survey by Statistics Department on January 24 and 25, 1994.

${ }^{35}$ Electric Utility Week, "Survey Finds Independent Power Plants Operate at High Availability Factors" (November 7, 1994$)$, pp. 14-15. 
Figure 7. Selected Winter Peak Demand Records, Week Ending January 22, 1994

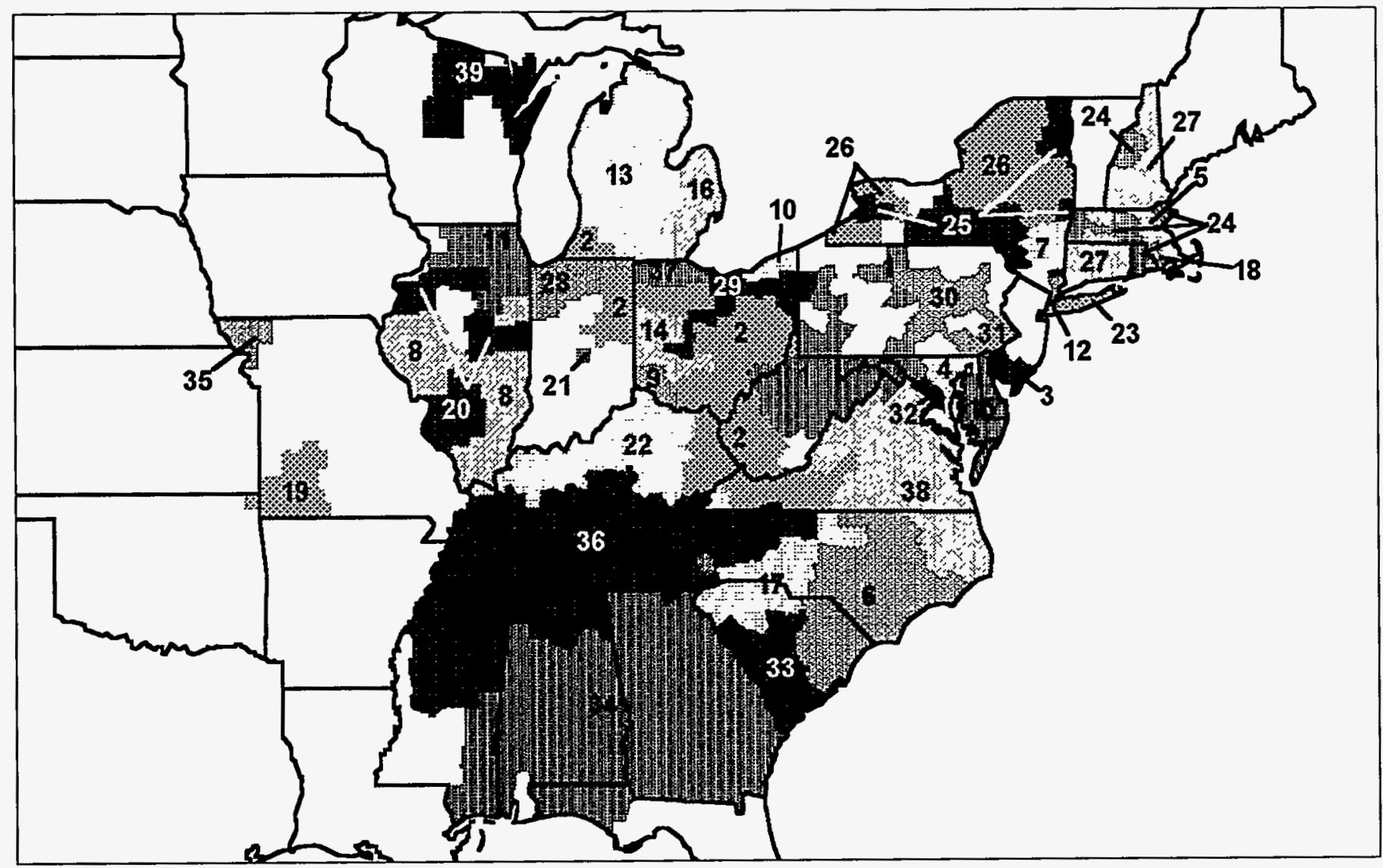

Notes: -See Table 2 for key to utilities. -Shaded areas show the service territories of the utilities.

Source: Edison Electric Institute, special telephone survey by Statistics Department on January 24 and 25, 1994. 
Table 3. Pennsylvania-New Jersey-Maryland Interconnection Assessment for January 19, 1994 (Megawatts)

\begin{tabular}{|c|c|c|c|}
\hline & Projected & Actual & $\begin{array}{l}\text { Percentage } \\
\text { Difference }^{b}\end{array}$ \\
\hline \multicolumn{4}{|l|}{ Demand } \\
\hline Internal Demand $\ldots \ldots \ldots \ldots \ldots \ldots \ldots$ & 40,182 & $c_{42,157}$ & 4.9 \\
\hline Direct Control Load Management $\ldots \ldots \ldots \ldots$ & 94 & 400 & 325.5 \\
\hline Interruptible Demand $\ldots \ldots \ldots \ldots \ldots$ & 795 & 600 & -24.5 \\
\hline Voltage Reductions $\ldots \ldots \ldots \ldots \ldots \ldots \ldots$ & 0 & 600 & NM \\
\hline Net internal Demand . . . . . . . . . . . & 39,293 & 40,557 & 3.2 \\
\hline \multicolumn{4}{|l|}{ Supply } \\
\hline Total Utility-Owned Capacity $\ldots \ldots \ldots \ldots \ldots \ldots$ & 54,571 & 52,229 & -4.3 \\
\hline Inoperable Utility Capacity . . . . . . . . . . & 0 & ${ }^{d}{ }_{12,346}$ & NM \\
\hline Net Operable Utility Capacity $\ldots \ldots \ldots \ldots$ & 54,571 & 39,883 & -26.9 \\
\hline Nonutility Generators . . . . . . . . . . . . . & 3,019 & 1,535 & -49.2 \\
\hline Capacity Purchases $\ldots \ldots \ldots \ldots \ldots \ldots$ & 535 & 3,584 & 569.9 \\
\hline Scheduled Utility Maintenance . . . . . . . . . . . & 2,797 & 4,985 & 78.2 \\
\hline Net Capacity Resources . . . . . . . . . . . . & 53,328 & 40,017 & -25.0 \\
\hline Capacity Margin (percent) . . . . . . . . . . & 26.3 & -1.3 & NM \\
\hline
\end{tabular}

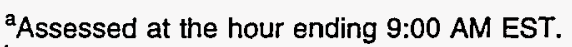

${ }^{b}$ Percentage difference was calculated as follows: the projected value is subtracted from the actual value and this difference is divided by the projected value and multiplied by 100 .

'Actual demand would have been even higher if public appeals and rolling blackouts had not been initiated.

Inoperable utility capacity was calculated by taking total inoperable capacity and subtracting all inoperable nonutility capacity, including scheduled maintenance.

$\mathrm{NM}=$ Not meaningful.

Note: Inoperable utility and nonutility capacity totalled 18,718 megawatts. This capacity was unavailable due to: fuel-related problems -26 percent, equipment failure -35 percent, start failure -4 percent, and miscellaneous problems -8 percent, along with planned utility outages of 27 percent.

Source: Projected: Energy Information Administration, "Review of January 1994 Cold Wave Incidents," Interim Draft Report (Washington, DC, June 24, 1994). Actual: Total Utility-Owned Capacity and Nonutility Generators-Facsimile from PJM Interconnection Association (Norristown, PA, September 2, 1994). Other-North American Electric Reliability Council, Report on Electric Utilities' Response to the Cold Wave of January 1994 (Princeton, NJ, April 11, 1994).

Figure 8. Projected vs. Actual Demand and Supply for the Pennsylvania-New JerseyMaryland Interconnection, January $19,1994^{\mathrm{a}}$

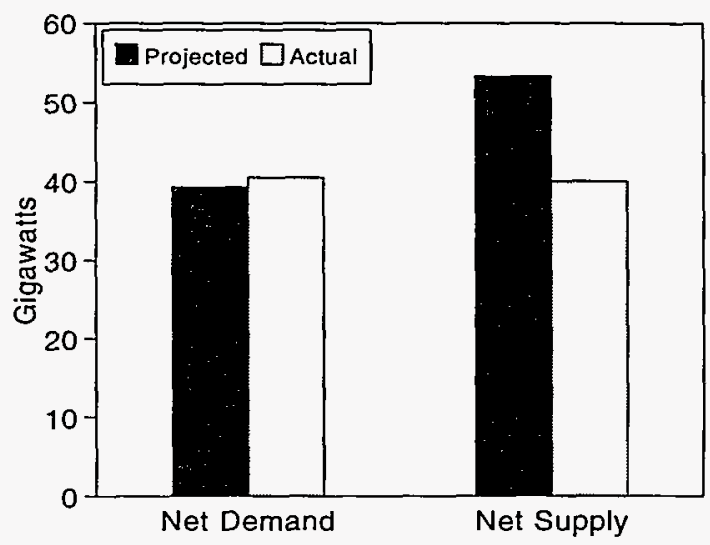

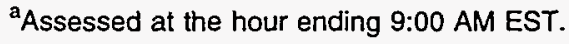

Note: Actual demand would have been even higher if public appeals and rolling blackouts had not been initiated.

Source: Projected: Energy Information Administration, "Review of January 1994 Cold Wave Incidents," Interim Draft Report (Washington, DC, June 24, 1994). Actual: Total Utility-Owned Capacity and Nonutility Generators-Facsimile from PJM Interconnection Association (Norristown, PA, September 2, 1994). Other-North American Electric Reliability Council, Report on Electric Utilities' Response to the Cold Wave of January 1994 (Princeton, NJ, April 11, 1994). 


\section{The Changing Structure and the Reliability of the Electric Power Industry}

The electric power industry in the United States is facing the prospect of substantial change in its structure and organization as it becomes a more competitive industry. ${ }^{36}$ Similar to the telecommunications and natural gas industries, the electricity industry may increasingly be made up of more enterprises under less regulation. Of course, this change is far from certain and is heavily dependent on the actions of Federal and State regulatory agencies as well as the legislative, executive, and judicial branches of both levels of government.

The reliability criteria for the electric power industry have largely been determined by electric utilities, and, since its inception in 1968, the North American Electric Reliability Council (NERC) and its member organizations. ${ }^{37}$ The electric utilities have had the responsibility for assuring that there is adequate supply of electricity to meet the needs of all customers in their service area and to follow proper operating procedures to maintain the security of the bulk power system.

In addition, reliability was often the same for most customers until expanding demand-side management programs with direct-control load management and interruptible service were implemented. Utilities now typically offer different levels of reliability, at different prices, to a small segment of their customers. Increased competition will lead to more customer choices, which will directly or indirectly be related to reliability of service. For example, for some customers, the economic trade-off in choosing a supplier of electricity will be based in part on the reliability of the supplier and the economics of different levels of reliability on the cost to the customer of unserved demand. Other customers will make their decisions strictly on price, but the reliability of service they receive may not be the same as from a higher priced supplier.

\section{Increased Wholesale Competition}

Several recent events have set the stage for change in the wholesale market of the electric power industry. Most of them are outgrowths of the Energy Policy Act of 1992 (EPACT).

Although the electric power industry is affected in numerous ways by EPACT, there are two major provisions that directly affect the structure of the industry. One creates a new class of electric power producers which are termed exempt wholesale generators (EWGs). EWGs are owners and/or operators of all or part of one or more facilities that generate electric power for sale at wholesale and that have been designated or are pending designation by the Federal Energy Regulatory Commission (FERC) as an EWG.

Designation as an EWG is important because an EWG is exempt from the limitations imposed on electric utilities by the Public Utility Holding Company Act (PUHCA) enacted in 1935. The important limitation of PUHCA in this regard is that public utility holding companies (companies that control a utility) that operate in noncontiguous States are limited to engaging in operating the utility and related activities only. This provision practically eliminated nonutilities from electricity generation for resale. ${ }^{38}$ Exempting EWGs from PUHCA allows virtually any business to generate electricity and sell it at wholesale.

The other relevant provision of EPACT substantially broadened the authority of FERC to order the provision of electricity transmission services under Section 211 of the Federal Power Act. FERC can now order a transmitting utility to provide transmission service, including

\footnotetext{
${ }^{36}$ For a discussion of the structure of the electric power industry, see Michael A. Crew and Paul R. Kleindorfer, The Economics of Public Utility Regulation (Cambridge, MA, The MIT Press, 1986).

${ }^{37}$ For a discussion of recent reliability criteria, see North American Electric Reliability Council, NERC Report of Regional Criteria and Guides for Planning Reliable Bulk Electric Systems (Princeton, NJ, November 1994).

${ }^{38}$ In 1978 , a relatively small group of electricity producers that qualified either as cogenerators or as generators energized by renewable fuels were exempt from PUHCA.
} 
the building of facilities needed to provide transmission at the request of any electric utility, Federal power marketing agency, or business generating electricity for sale at wholesale.

EPACT has little to say directly about the reliability of the electric power system. Section 721 does limit FERC to not issuing any order for transmission, "if after giving consideration to consistently applied regional or national reliability standards, guidelines, or criteria, the Commission [FERC] finds that such order would unreasonably impair the continued reliability of [the electric power system]. ${ }^{\prime 39}$ No specific levels of reliability are required by the act.

\section{Regional Transmission Groups (RTG's)}

The formation of Regional Transmission Groups (RTG's) was under consideration by Congress during its deliberations on EPACT. RTG's, as proposed, would be voluntary organizations of transmission owners, users, and other entities interested in coordinating transmission planning, expansion, operation and use on a regional and interregional basis. The groups would have broad membership and members owning transmission facilities would be obliged to wheel power for others and upgrade their system or build new facilities as required. The groups would establish equitable procedures for decision making and dispute resolution.

Although the proposal was not included in the final EPACT legislation, FERC believed that RTG's could satisfy the goals of EPACT concerning open access to transmission lines for promoting competition, improving efficiency in bulk power markets, and reducing the cost of electricity to consumers without potentially time-consuming and expensive litigation before FERC. FERC, therefore, issued a request for public comment on the RTG proposal in November 1992 and then adopted a general statement of policy regarding RTG's. The policy statement is designed to allow sufficient flexibility for various creative solutions, while at the same time ensuring that RTG agreements are just, reasonable, and not unduly discriminatory or preferential. It states that the Commission encourages RTG's as a means of enabling the market for electric power to operate in a more competitive and efficient way and that the Commission believes that RTG's can provide a means of coordinating regional planning of the transmission system and assuring that system capabilities are always adequate to meet system demands.
Any proposed RTG agreement, that in any manner affects or relates to the transmission of electric energy in interstate commerce by a public utility, or rates or charges for such transmission, must be filed with FERC for approval under the authority of section 205 of the Federal Power Act because they represent contracts affecting or relating to transmission services provided by public utilities. Any public utility member of a proposed RTG may file the RTG agreement with FERC on behalf of the other public utility members.

Three proposed RTG's have formally applied to FERC for approval: Southwestern Regional Transmission Association, Western Regional Transmission Association and Northwest Regional Transmission Association. The first two have been approved conditionally.

\section{New Wholesale Market Participants}

New institutions and methods of operating are being developed in the wholesale market for electric power. They include electronic bulletin boards that provide information on offers to buy and sell, brokers that bring buyers and sellers together, marketers that buy and sell bulk power, and futures markets that provide standard financial instruments to hedge future commitments in the wholesale power market.

While some have been in existence for a while, several new electronic bulletin boards have been set up to provide information to wholesale electric power buyers and sellers. Bulletin boards only provide information to market participants, they are not involved in any transaction. However, more sophisticated versions may actually complete a transaction electronically between a buyer and seller.

Several brokers have entered the wholesale electric power market to facilitate transactions between buyers and sellers. By and large brokers are in the business of providing information and expediting transactions. Their activities include gathering information from potential buyers and sellers, bringing together buyers and sellers that appear compatible, and facilitating a transaction between them. Marketers have also entered the wholesale power market. Marketers usually buy and sell power themselves, although they may sometimes act as brokers, but do not generate power or sell it to end users. Marketers can complete one side of a transaction when there is no electric power generator or seller to end users available to complete the other side. Later, the marketer completes the other side of the

\footnotetext{
${ }^{39}$ An amendment to the Federal Power Act, Section 211 (16 U.S.C. 824j) contained in EPACT.
} 
of the transaction so that it need not generate or sell at retail any electricity.

Because they take part in wholesale electric power transactions and FERC regulates wholesale electric power transactions, marketers come under the jurisdiction of FERC. FERC must certify bulk power marketers and approve the terms of any wholesale transaction. In the middle of August, FERC had certified about 40 marketers. Enron Power Trading and Transmission, Louis Dreyfus, North American Energy Conservation, Torco Energy, and Howell Power Systems have completed several transactions.

The New York Mercantile Exchange (NYMEX) is in the process of developing a standard contract for wholesale electricity trades to take place at some future time. The standard contract differentiates the futures market from the regular wholesale market. The contract specifies that a certain amount of electricity will be delivered to a certain place under certain conditions over a certain period of time. Thus, each futures contract is for the same amount of electricity with the same characteristics at the same location; only the time period of delivery changes. The futures market is primarily used to reduce financial risk, but reducing risk may also improve the operation of the bulk power system by providing increased information.

Actual delivery of electricity occurs infrequently with futures contracts. Instead, they are a financial instrument that allows wholesale market participants to hedge their position. For example, an electric power generator that plans to sell electricity at some future time at the then current market price may buy a futures contract now at a specified price to offset that commitment. Then the generator can purchase electricity at the market price at time of sale, offsetting its sale at the market price (ignoring transactions costs). As a result, the generator effectively sells the electricity at a future time at the current futures price minus any transactions costs.

\section{NERC Assessment}

The latest NERC report on reliability ${ }^{40}$ states that they expect wholesale competition will result in an increase in the number of participants in the electricity market along with the number and magnitude of electricity transactions. However, the security aspect of the reliability of the bulk electric power system will still be the responsibility of the relatively few entities that operate control areas. (Currently, there are around 140 control areas in the United States.) This outcome is likely because of the instantaneous nature of electricity and how it flows through a transmission network.

NERC argues that the operation of the system will become more complex, requiring more system operator training and computer software, more sophisticated monitoring devices to assess the state of the system, and authority for operators to take timely action to ensure reliability. ${ }^{41}$ All electricity suppliers in the competitive wholesale market must be required to meet NERC and the Regional Councils reliability criteria, standards and guidelines including:

- frequency regulation

- voltage control

- reactive power generation

- interchange scheduling

- time error correction and inadvertent energy balancing

- operating reserves

- load following.

NERC also identifies the need for a security staff, separate from the competitive part of the wholesale electricity market, to assure compliance with reliability procedures on a real-time basis. The security function will require a comprehensive communications and information sharing network, real-time information on all transactions using the transmission systems, and authority to order immediate changes in operation when interconnected system security is at risk.

\section{Retail Competition}

The most far reaching proposed change to the electric power industry is the restructuring of the industry to allow customers to choose their electricity supplier in a competitive market. This is referred to as retail wheeling. The effect of this change on performance is uncertain because how the restructuring will occur is not specifically defined. Therefore, it is not even clear who will have the responsibility for planning for adequate supplies of electricity, i.e., the electric utility, a disaggregated transmission and distribution or wheeling company, each electricity generation supplier, or the customer.

Some of the ongoing utility related programs such as demand-side management programs, that affect

${ }^{40}$ North American Electric Reliability Council, Reliability Assessment 1994-2003 (Princeton, NJ, September 1994), pp. 7-10.

"North American Electric Reliability Council, Reliability Assessment 1994-2003 (Princeton, NJ, September 1994), p. 10. 
reliability, may also change with competition. At least nine States currently have proposals or legislation for retail wheeling-California, Connecticut, Illinois, Michigan, Nevada, Ohio, Texas, Utah, and Vermont. It is useful to examine some of their proposals and how they have addressed reliability to assess the possible impacts on future performance.

\section{Connecticut}

The State of Connecticut's Department of Public Utility Control opened an investigation into retail electric transmission service (Docket No. 93-09-29). Two utilities, Connecticut Light and Power and United Illuminating, and the New England Power Pool (NEPOOL) provided comments on reliability issues associated with the implementation of retail wheeling.

The two utilities assumed that they would retain their present structure, that is, an integrated utility company with generation, transmission and distribution facilities. The issues identified were:

- System Planning for the utility's reliability will become more difficult because of greater uncertainty in load forecasting due to competition for retail customers. If customers are allowed to come and go from the regulated utility system in an unrestrained fashion, and utilities are required to serve returning customers, it will be more difficult for the utility to maintain enough generating capacity for reliability and remain economically competitive. Initially, this may not be a problem because both utilities, due to depressed demand growth, have enough existing supply to meet expected loads until 2000 to 2010. However, increased competition will put more emphasis on lowering short-term costs rather than optimal long-term planning with less emphasis on fuel diversification and environmental impacts.

- Transmission and Distribution planning will also be more difficult with retail wheeling because the location of future electricity supply will depend on the customer's choice of supplier. Any resulting shifts in electricity flows could be beneficial or detrimental to the transmission and distribution system, i.e., requiring or deferring upgrades to the system. ${ }^{42}$
- Cost and/or Allocation of Reliability Services must be determined so that there is an understanding of the responsibilities for reliability among retail suppliers. The electric utilities currently provide important functions, support services, and procedures for a reliable electric system, such as: backup/standby capacity, spinning or operating reserves, load following, voltage control, reserve transmission capacity, frequency control, and protective equipment. A number of these services cannot be disaggregated, but for some services or procedures, it may be appropriate for the supplier of the electricity to be responsible. For example, the supplier may be responsible for providing backup generation or having interruptible service agreements with their customers and the supplier may have some minimum operating requirements imposed on them similar to utilities that are part of a power pool. A tariff structure for retail wheeling will have to be determined to allocate reliability costs properly and equitably. The tariff would include all capital, operating and maintenance, and other costs associated with providing transmission and distribution services. To assure reliability, the tariff would also include costs of reliability related services that the utility provides.

NEPOOL is a power pool servicing the six New England States. The individual utility members of the power pool plan new capacity for their systems based on cost, as well as consideration of pool-wide impacts. Once capacity is constructed by the utility or obtained under a purchase contract, the capacity is turned over to NEPOOL to control and dispatch with the pool operated as one interconnected utility. The primary purpose of NEPOOL is to assure system reliability, however, economic benefits have also been realized. NEPOOL expects that retail wheeling will add to the system's complexity and make the task of maintaining reliability increasingly difficult especially if retail wheeling occurs with entities outside the NEPOOL system.

NEPOOL has criteria, rules and standards, and operating procedures based in part on those established by NERC and the Northeast Power Coordinating Council for utility members to follow. Some are non-binding and are effective only because of good faith commitments and mutual benefits. The degree to which nonutility providers can be compelled to comply with such guidelines in a competitive environment is unclear.

\footnotetext{
${ }^{42}$ Electricity flow is more complex than flows of petroleum products or natural gas through a pipeline. Electricity flows instantaneously and takes the path of least resistance. For example, power will be distributed equally on three paths if the impedance between the generator and the load are equal on all three lines. If the impedances differ, the power will be distributed in inverse proportion to the impedance and if one line is removed the power will redistribute itself along the remaining two lines. If overloading occurs, the overloaded line will trip and can cause a cascading effect. Meters on lines send power flow data to control area computers. Frequency and voltage control must also be maintained to prevent tripping a generator or customer load and to prevent damage to the components of the bulk power system, and for other reasons.
} 
To evaluate the impact of retail wheeling on reliability, it is necessary to determine the extent to which suppliers should be required to comply as a condition to have access to the system. NEPOOL would expect operating reserves and planning reserve capacity requirements to increase with increased levels of retail wheeling because of the increased uncertainty about future load.

\section{Michigan}

The Michigan Public Service Commission issued an order on retail wheeling on April 11, 1994, related to Cases No. U-10143 and U-10176. The Commission established some terms and conditions for implementing an experimental retail wheeling program and will continue hearings on such issues as the pricing of retail delivery service. The program, as proposed, will be 5 years in duration and limited to 60 megawatts of retail delivery capacity for Consumers Power Company and 90 megawatts for Detroit Edison Company. The timing for each utility's retail wheeling program to begin will be coordinated with the need for new capacity. This should help eliminate the possibility of stranded investments. ${ }^{43}$

Some of the terms and conditions established for retail wheeling are designed to assure reliability for customers that remain with the electric utilities and to inform customers, that choose to participate in the experimental program, of their rights and responsibilities concerning reliability. The experimental program is designed to gain information on the effects of retail wheeling on the reliability and safety, the administrative burdens and technical complexity, and the costs and efficiency of existing utility operations.

The following constraints, that address reliability, were placed on participating customers:

- Customers participating in the experiment have the option of paying the utility for standby capacity equal to their retail delivery capacity, making their own standby arrangements, or having interruptible service. However, if they do not contract with the utility, their load must be physically capable of interruption. In such cases, their electricity service will be interrupted by the utility, if their primary and standby suppliers fail to produce enough power.

- Customers participating in the program will be able to return to full utility service after the program's expiration on the same terms as any nonparticipating customer. They will also be permitted to return to full utility service prematurely; however, the rate they pay for electricity will be determined by the cost of the incremental power supply resources beyond those required to serve other retail customers. They will also be subject to interruption to maintain system integrity.

- Participating customers will not be permitted to engage in reassignments of deliveries of power unless they obtain the local utility's consent. This helps to assure reliability of the transmission system.

The current schedule for the Michigan Public Service Commission has proceedings on the retail wheeling proposal continuing until March 13, 1995.

\section{California}

The Public Utility Commission of the State of California issued an order instituting a rulemaking and an order instituting an investigation into restructuring California's electric services industry and reforming regulation. The proposed program would permit some consumers to choose among competing generation service providers by January 1,1996 and all consumers by January 1,2002 . Simultaneously, the traditional costof-service regulation will be replaced with performance based regulation.

The Commission's goal is to accomplish the proposed strategy while maintaining California's reliable electric service. They point out that wholesale power markets have not compromised safety or system reliability within a specific utility's service territory or the West and have tended to enhance reliability. In general, the Commission expects that the restructured electric services industry will function similar to the Western Systems Power Pool. The ownership of the electricity generation infrastructure is separate from the use of the infrastructure. The Pool is centrally managed with a single computer providing central control and coordination necessary for efficient, safe, and reliable operations. Sophisticated telecommunications technology provides a way to engage in short-term trades for electric energy, capacity, exchanges and transmission services.

Current institutional arrangements governing the power markets and pools will be applied to all competitive suppliers to provide for adequate system control, coordination and reliability, and the financial and

\footnotetext{
${ }^{13} \mathrm{~A}$ stranded investment is an investment with a cost recovery schedule that was initially approved by regulatory action that subsequent regulatory action has rendered not practically recoverable.
} 
technical arrangements. Independent power producers have already begun playing a role in reliability planning. The Western Systems Coordinating Council (WSCC) recently broadened its membership to include independent power producers and they are also active participants in the development of the Western Regional Transmission Association. Qualifying facilities are now able to become a member of and participate in the Western Systems Power Pool due to a recent FERC order. Regional transmission groups may provide another institution for facilitating access to the transmission grid. Regional transmission groups may merge with industry-led pools and reliability councils to form an integrated market or markets for transmission in the West.

In addition, the New York Mercantile Exchange plans to open its first futures contract for electricity in the West. The futures contract is an instrument for buyers and sellers to manage risk by guaranteeing the future price.

\section{Changes in Demand-Side Management}

As the future of the electric utility industry gravitates towards more retail competition, the debate over demand-side management (DSM) and its place in that industry has recently come to life. Projections of DSM effects play a role in reliability planning. For example, effects of DSM programs such as conservation programs, improvements in efficiency of electric energy use, rate incentives, and rebates are included in NERC's projected peak load demands (see Appendix A-Capacity Margins). ${ }^{44}$ The projected effects of these programs are a contributing factor to the flattening of projected summer peak increases in the late 1990's.

Predictors of the eventual demise of the current concept of DSM in a deregulated industry share the idea that promotion of decreased sales of electricity through rebates or cost savings to certain customers can ideally work only in a regulated environment. The costs are recouped from all customers of a regulated utility since they benefit from lower requirements for new supply. This form of DSM, it is argued, will become obsolete with retail competition as electric utilities try to reduce their costs to retain their customers. Many of the goals of DSM programs may, however, be achieved through free market pressures. For instance, electricity providers in a deregulated environment may have an incentive to lower heat rates of their fossil-fired plants in an attempt to reduce fuel costs, allowing flexibility to increase profits or lower rates to be more competitive.

On the other hand, many worry that a fully deregulated electric utility market without DSM programs will not achieve many of the current goals of DSM. Also, there is concern about environmental issues. Too many environmental externalities may leave the market unable to efficiently achieve environmental goals currently targeted in DSM programs.

The future of DSM is an issue that regulators will need to look at when and if they further relinquish control over the industry. The goals of DSM and the ability of a new industry structure to achieve them, with or without DSM programs formally present, will need to be evaluated.

\section{Customer Choice of Reliability of Supply}

Utilities have long had programs that allow a small number of customers to affect the level of reliability of their electric power service. These programs include the common feature that the customers choose a set of conditions under which their electricity service may be interrupted in return for a lower rate. In recent years, particularly with the advent of DSM and cheaper metering costs, these programs have become more popular and have been extended to more customers.

\section{Interruptible Service}

In interruptible service, the utility specifies conditions under which it is not required to provide electricity service to the customer in combination with an electricity price that is lower than for noninterruptible service. ${ }^{45}$ By limiting service under certain conditions, this plan affects the reliability of service to individual customers. Many customers choose interruptible service to lower their electricity rates. ${ }^{46}$

When capacity margins are high, interruptible customers rarely get interrupted. However, as margins decline, many interruptible customers may experience lower reliability and may choose to change to noninterruptible service. As capacity margins reach optimum levels, customers will begin to understand the actual tradeoffs they are making between price and reliability.

\footnotetext{
${ }^{4}$ North American Electric Reliability Council, Electric Supply and Demand 1994-2003 (Princeton, NJ, June 1993), p. 4.

${ }^{45}$ Interruptible service does not obviate the need to choose the basic reliability level of the electric power system.

${ }^{16}$ These choices also provide information about the value of electricity service to customers.
} 
It is analogous to using a market to determine reliability levels. Thus it provides many of the advantages and disadvantages associated with markets. Electricity service, including reliability, will be provided efficiently but not necessarily equitably, if the market works well at allocating resources. However, under some conditions markets do not work well, so that neither electricity nor reliability is supplied efficiently.

\section{Real-Time Pricing}

In real-time pricing, electricity is always available to all customers who want to purchase it at the specified price, which may be very high at certain times when demand is high relative to supply. In this case, the customer chooses when the availability of service will be interrupted based on a time-of-use price. In its pure form, real-time pricing programs virtually never incur forced outages. The reliability level for the customer is implicitly affected by the customer making the choice between taking or not taking electricity, given its price at any particular time. If customers choose to pay high prices for electricity when it is expensive to produce, electricity producers will have an incentive to provide more reliable service.

This result is obtained by varying the price of electricity over time so that no consumer desiring service at the market-clearing price will not receive it. Of course, this practice on occasion will result in very high prices for relatively short periods of time. To the extent that realtime pricing encourages electricity conservation, it may be a replacement for DSM programs.

\section{New Technologies}

Improved methods of recording information, communicating information, and manipulating information will allow customers to have more choice in the reliability level they face. For example, in conjunction with realtime pricing for customers, periodically communicating the price of electricity from the utility to the customer will allow the customer or a computer to decide whether to operate certain electrical equipment during the period. The cost of these information technologies has been decreasing rapidly.

Two-way communication between utilities and their customers allows the electricity service at any location to be controlled by the utility under previously defined conditions. For example, some utilities can already directly control the flow of electricity to certain major appliances like an air conditioner or water heater.
Setting conditions under which the utility may interrupt that flow is one way to affect the reliability of electricity service to the customer. Further, different conditions allow reliability levels to be tailored to individual consumers.

New technologies to transmit or store electricity also provide the potential to improve the reliability of the electric power system. Most transmission circuits are currently using mechanical switches. Solid state switches (thyristors) currently being tested are much faster and will allow more electricity to be transmitted over existing lines. Cheaper storage of electricity will make it more economical to store electricity to be available when the system is not functioning properly.

\section{Other Issues}

Consumer choice of the level of reliability that is appropriate for their electricity service has been limited historically because there has been little opportunity for consumers to choose among alternative levels of reliability in the marketplace. Instead, a franchised utility with regulatory oversight and the North American Electric Reliability Council guidance, acting as a monopoly in each service area, usually chooses a reliability level for customers. Exacerbating the problem is that electricity service usually is provided as a bundle of different products and services including the electricity itself and its reliability of delivery. However, resources are required to ensure reliability. A more reliable electric power system costs more to construct, maintain, and operate than a less reliable system. Thus the level of reliability of delivery must be chosen, not only in conjunction with the price of reliability, but also in conjunction with the price of the electricity itself.

\section{Price}

Price is how much the end user pays for electricity. In most cases, there is not just a single price for electricity, but many prices that are determined by a combination of different rules which may become rather complex. In addition to the quantity of electricity that is supplied to the end user, these rules often depend on whether the end user is a part of any demand-side management program, what consumer class (residential, commercial, industrial) the end user is a member of, and on other characteristics of the end user. When electricity prices are given as a single number, say 5 cents per kilowatthour, that number is usually an average of several different prices. 
For example, end users may pay a different price for using small amounts of electricity than for using large amounts; residential customers may pay different prices than commercial customers, who may pay different prices than industrial customers. Other pricing methods that have become more prominent recently are components of demand-side management programs that attempt to even out the demand for electricity over time. One of these is based on the degree to which customers agree to allow their supply of electricity to be interrupted, including by direct or indirect utility control. Another method is based on how much electricity is being demanded and how expensive it is to generate.

\section{Reliability of Supply}

Reliability of supply is the probability that end users will be able to obtain as much electricity as they would like at a particular time. This includes the reliability of the entire interconnected system, which depends on the reliability of each component of the system. One measure of reliability of supply is how often some users are expected to lose electricity service. There are many ways to actually calculate the reliability of an electric power system, but they are usually derived from this general principle. Since reliability is the average of a large number of individual events, it cannot describe an individual event, but only the group of events taken as a whole.

\section{Trade-Offs}

Economic actions require the consideration of trade-offs, where in order to obtain more of one thing you must give up something else; put more succinctly, everything has a cost. The reliability of electricity supply is no exception to this rule; it costs more to produce and deliver higher levels of reliability. ${ }^{47}$ The fundamental economic question regarding reliability is how much do we want to pay for what level of reliability.

In general, the price of something is affected by the cost of producing it. Since reliability affects the costs of providing electricity, the price of electricity in part reflects the reliability of its supply.

\section{Uncertainty}

The effects of current decisions on future events is usually not known with certainty. Thus planning for the future is a difficult and unpredictable business. When planning the electric power system, it is important to understand that the probability of a power system outage can be affected by increased spending on improving reliability, but the actual occurrence of an outage may not be affected. For example, you may spend a large amount of resources in 1 year to reduce the probability of an outage and fewer resources in the next year, increasing the probability of an outage in the next year. Yet two outages may occur in the first year, and only one in the second year. The probability of an outage was lower in the first year than in the second, but the occurrence of outages was higher in the first year than in the second. ${ }^{48}$

Furthermore, the appropriateness of past decisions cannot be determined solely by actual outcomes. If you plan for a certain level of reliability, and then an outage occurs, that does not mean that the level of reliability chosen was inappropriate. This is because only expected reliability levels can be chosen, not actual levels. Expected reliability levels can only be evaluated by considering the conditions at the time the decision was made, not the outages that occurred later. ${ }^{49}$ For a more detailed discussion of the economics of electric power reliability, see Appendix B.

\section{Summary}

Some entity similar to control area operators must continue to have the ultimate responsibility for the reliable operation of the bulk electric systems. The specifics of how that adequacy and security will be maintained during a period of changing structure for the industry have not been established. However, a few observations may yield some insight.

The structure of the electric power industry appears to be moving toward a greater number of owners and a more diverse ownership of electricity generating

\footnotetext{
${ }^{47}$ Economics studies usually assume that production is occurring in the least cost manner. Thus they have little to say about reducing costs while producing the same amount of electricity with the same reliability.

${ }^{48}$ Over a large number of years, the number of outages in higher spending years will usually be lower than the number of outages in lower spending years.

${ }^{49}$ Actual outages can of course be used to estimate expected outages and to measure the accuracy of expectations regarding reliability when the decision was made. Given a number of observations, outcomes can be used to test accuracy but not appropriateness.
} 
capacity as well as smaller generating units. While this trend may pose problems for coordinating the planning and operation of a reliable bulk electric power system, in a statistical sense with all other things equal, greater numbers, more diversity, and smaller units have often been associated with increased reliability. ${ }^{50}$

Electric power prices and availability conditions to customers seem to be becoming more diverse. This suggests that customers will be able, to some extent, to choose the reliability of their own electricity service through interruptible service, real-time pricing, or payments for backup capacity. A movement toward more consumer choice in reliability suggests that consumers may be better served. However, these reliability choices by each consumer are separate from the reliability of the bulk power system as a whole.

The legal requirements for utilities to furnish adequate and reliable service to customers as a condition of their franchise most likely will be revised with retail wheeling. For example, some conditions regarding noti- fication will need to be met before a utility will be responsible for providing service to a customer that previously had chosen a different supplier. Nonutility providers of electricity may increasingly become members of the regional electric reliability councils and be required to follow the NERC and regional reliability criteria and guides concerning operating reserves, load following, voltage control, etc.

The movement toward more customer choice in reliability is a movement away from central (utility) planning to determine reliability. The movement has several antecedents, including the telecommunications and natural gas industries ${ }^{51}$ in the United States and the electric power industry in Great Britain. In each of these cases, there have been no obvious dire consequences for reliability. For the movement to be successful, the markets in which electricity is sold must function well. The future reliability of the electric power system may depend as much on a commitment to making electricity markets function well as it does on planning for that reliability.

${ }^{50}$ Regarding greater numbers see Paul L. Joskow and Richard Schmalensee, Markets for Power (MIT Press, Cambridge, MA, 1983), pp. 48 and 53 and p. 228, fn. 9. For evidence that smaller electricity generating units have been more reliable than larger ones, see Paul. L. Joskow and George A. Rozanski, "The Effects of Learning by Doing on Nuclear Plant Operating Reliability," Review of Economics and Statistics, v. 61 (May 1979), pp. 161-168 and Charles Komanoff, Power Plant Cost Escalation, Komanoff Energy Associates (1981).

${ }^{51}$ Admittedly, the problems of operating these systems are technologically simpler than for electricity. 

Appendix A

Historical Trends in Reliability-Related Data 
• 


\section{Appendix A \\ Historical Trends \\ in Reliability-Related Data}

The U.S. generating capacity margin (including both the grid-serving portion of nonutility capacity and utility capability) showed an increasing trend in the mid-and late 1970's and early 1980's reaching 33 percent in $1982 .{ }^{[52]}$ It then declined to 21 percent in 1993 as utilities built fewer new generating units. Nonutility capacity, however, grew at a rapid rate after 1984. U.S. capacity margins, including the estimated effects of demand-side management and nonutility capacity, are projected to decline to 17 percent by 2003 . Because of the leadtime historically required for acquiring new capacity, planning for reliability requires projecting supply and demand trends for up to 10 years into the future.

These data are presented in this appendix, along with highlights of additional data and forecasts concerning the factors that have historically affected the planning of reliability. Detailed data are presented for several specific factors in each of the three main areas-capacity margins, supply trends, and demand trends. These data provide a useful picture of the U.S. electric power system.

The intention of this appendix is to provide many different data in the form of a reference. With the changing structure of the electric power industry, the factors involved in planning the reliability of the system will most certainly be changing. It is possible that some of the factors referenced in this appendix will no longer have an impact on reliability planning. Therefore, these data are included to provide a view of reliability planning in a historical context as the industry transforms.

\begin{tabular}{|l|l|}
\hline \multicolumn{2}{|c|}{ List of Acronyms for Appendix A } \\
\hline CAAA90-Clean Air Act Amendments of 1990 & MAIN-Mid-America Interconnection Network \\
\hline DSM-Demand-Side Management & MAPP-Mid-Continent Area Power Pool \\
\hline $\begin{array}{l}\text { ECAR-East Central Area Reliability Coordination } \\
\text { Agreement }\end{array}$ & NERC-North American Electric Reliability Council ${ }^{\text {a }}$ \\
\hline EIA-Energy Information Administration & NPCC-Northeast Power Coordinating Council \\
\hline EPACT-Energy Policy Act of 1992 & $\begin{array}{l}\text { PURPA-Public Utility Regulatory Policies Act of } \\
1978\end{array}$ \\
\hline ERCOT-Electric Reliability Council of Texas & SERC-Southeastern Electric Reliability Council \\
\hline FGD-Flue Gas Desulfurization & SPP-Southwest Power Pool \\
\hline MAAC-Mid-Atlantic Area Council & WSCC-Western Systems Coordinating Council \\
\hline & \\
\hline
\end{tabular}

Endnotes and figure notes are at the end of the Appendix. 


\section{Capacity Margins: Calculations and Definitions}

There are two different ways to determine the adequacy of a utility's generating capacity-the capacity margin and the reserve margin. In both cases, peak demand is subtracted from capability in the numerator. The difference in these two measures, however, is the denominator. For a capacity margin (as described in detail following this introduction), the denominator is capability, while reserve margins have peak demand. Reliability criteria vary by NERC region and include both capacity margins and reserve margins, depending on the region. Capacity margins are highlighted in this report because that is the terminology used by NERC in its reports.

Capacity margins indicate "the amount of generating capacity available to provide for scheduled maintenance, emergency outages, system operating requirements, and unforeseen electricity demand." They offer an indication of how much electricity will be available after peak demand has been met in normal situations. However, "capacity margins are not sufficient indexes of electric supply adequacy. ${ }^{\prime[53]}$

The two main data series used in calculating capacity margins are peak demand and capability. Peak demand is the highest demand that a system serves plus the losses incidental to that service. The peak demands for the contiguous United States are aggregates of the seasonal peak demands of the NERC regional councils, where the majority of the regional data represent noncoincidental seasonal peaks. Summer peak demand is used in this report because the United States generally has higher demand in the summer than in the winter. The summer period is June 1 through September 30 . Also in this report, net summer capability is used whenever possible, as it is a measure of maximum capacity as demonstrated by tests at the time of summer peak demand. ${ }^{[54]}$

The historical capacity margins in this report were calculated using actual peak demand and net summer capability (in megawatts), ${ }^{[55]}$ with the following formula:

$$
\frac{\text { SumCap-PeakDem }}{\text { SumCap }} * 100
$$

where,

SumCap = Net Summer Capability, and

PeakDem $=$ Peak Demand.

'SumCap' is the sum of utility net summer capability and the grid-serving portion of nonutility capacity in calculating the capacity margin for the total U.S. electric power industry.

Projected capacity margins are NERC capacity margins that are calculated using the following formula (in megawatts): ${ }^{[56]}$

$\frac{\text { PlanUtil }+ \text { PlanNug-PeakDem }+ \text { DCLoad }+\operatorname{IntDem}}{\text { PlanUtil }+ \text { PlanNug }} * 100$

where,

PlanUtil = Planned Utility Capacity Resources, PlanNug = Planned Nonutility Capacity Resources, PeakDem $=$ Peak Demand, DCLoad = Direct Control Load Management, and IntDem = Interruptible Demand.

Planned utility capacity resources include existing units, planned or proposed units, and planned capacity purchases, and exclude inoperable capacity and planned capacity sales.

Endnotes and figure notes are at the end of the Appendix. 


\section{Capacity Margins and Adequacy} Figure A1. Variation of Reliability with
Capacity Margin

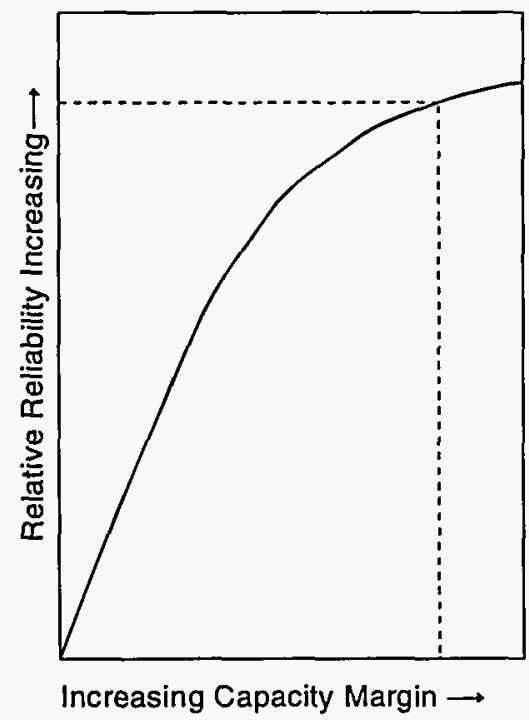

Figure A2. U.S. Capacity Margin, 1973-1993

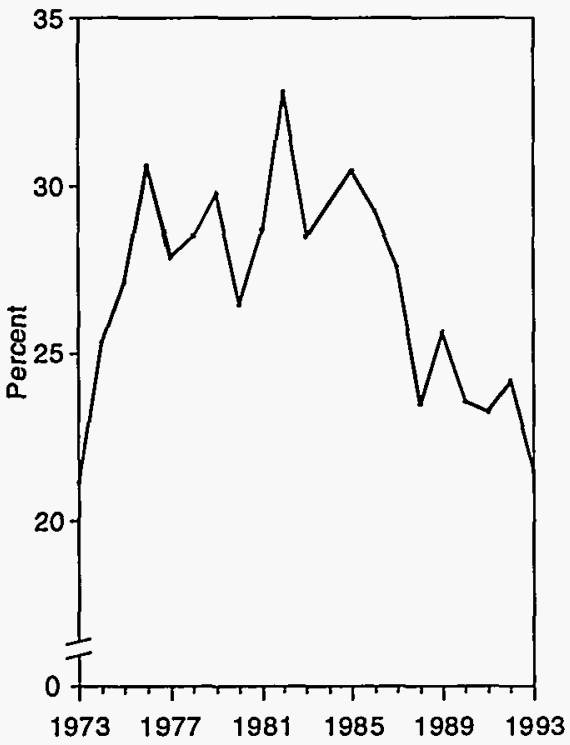

- "From the earliest days of electric power systems, a generating capacity margin has been known to be essential for reliable service." However, "there were no analytical tools to determine numerically the level of reliability resulting from a selected level of installed capacity."

- The numerical calculation of the capacity margin is a simplified version of the more complex idea of projecting whether an electric system will be able to meet demand. Minimum levels of acceptable capacity margins are determined by the system, control area, or the regional council. The utility must have a plan to meet demand using existing capacity resources, or with capacity additions and increased electricity trade. ${ }^{[58]}$

- The utility must also consider how much its customers are willing to pay for added reliability. "Acceptable levels of reliability are somewhat judgmental, but they reflect a thoughtful cost-benefit evaluation" (Figure A1). ${ }^{[59]}$ If the capacity margin is low, an increase usually translates to greater relative reliability. Conversely, if the capacity margin is high, an increase will probably not have much or any benefit.

- The aggregate U.S. capacity margin has shown a declining trend after 1982, and dropped to 21 percent in 1993 (Figure A2).

- The U.S. capacity margin showed an increasing trend in the mid-and late 1970's and early 1980's until it peaked at 33 percent in 1982. This increase was due to the major growth in electric utility coal-fired and nuclear capacity. These additional plants were built to meet a forecast peak demand that was much higher than the peak that actually occurred. Large utility capacity margins exhibited in the 1980's were not needed to assure the minimum required level of reliability, although these higher margins did allow utilities to minimize the running of higher fuel cost units. Economic factors associated with financing and more stringent regulatory review of utility costs by State regulators made utilities reluctant to build new electric generating capacity by the late 1980 's. 


\section{Regional Projections of Capacity Margins}

- Projections for capacity margins in the nine U.S. NERC regions differ greatly due to different reliability criteria. Each region establishes a criteria based on the regions's individual circumstances. ${ }^{[60]}$ Two regions are reviewed in detail in the following bullets.

- The capacity margin in NPCC is higher than most of the other regions (Figures $\mathrm{A} 3$ and $\mathrm{A} 4$ ) for several reasons. In the 1980 's, the region was experiencing capacity shortfalls because of a booming economy and delays in capacity coming on-line. Many strategies were put into play to alleviate this problem, including initiating demand-side management programs and planning nonutility sites. By the early 1990's, the economy slowed and loads dropped for 2 consecutive years. At the same time that demand dropped, more capacity became available from a nuclear facility that came on-line, a power purchase agreement with Hydro Quebec, and new nonutility facilities that utilities were required to purchase. This all combined to form higherthan-planned capacity margins, and current plans show the projected capacity margins for NPCC falling more between 1994 and 2003 than for most of the other regions.

- The capacity margin in 2003 for the MAPP region is projected to be almost 3 percentage points less than that for the next lowest regions. Through 2000, capacity plans are adequate to meet projected demand; however, by 2003,850 megawatts of additional capacity will be needed to maintain the required reliability criteria. ${ }^{[61]}$ Therefore, the capacity margin drops after 2000 reflecting the uncommitted capacity. Utilities in MAPP are committed to maintaining adequate supply, so reliability will not be affected. Most of the capacity additions will be short lead-time projects such as combustion turbines, to which the utilities are not yet committed.

- NERC planned additions include capacity that is presently committed as well as capacity that is only proposed. Proposed capacity additions include units where specifics about the unit, such as prime mover or fuel source, have not yet been determined, thereby adding flexibility to a utility's planning. These units are included in the capacity additions because the capacity is needed to meet projected demand.
Figure A3. Projected Capacity Margin for the Eastern United States by NERC Region, 1994-2003

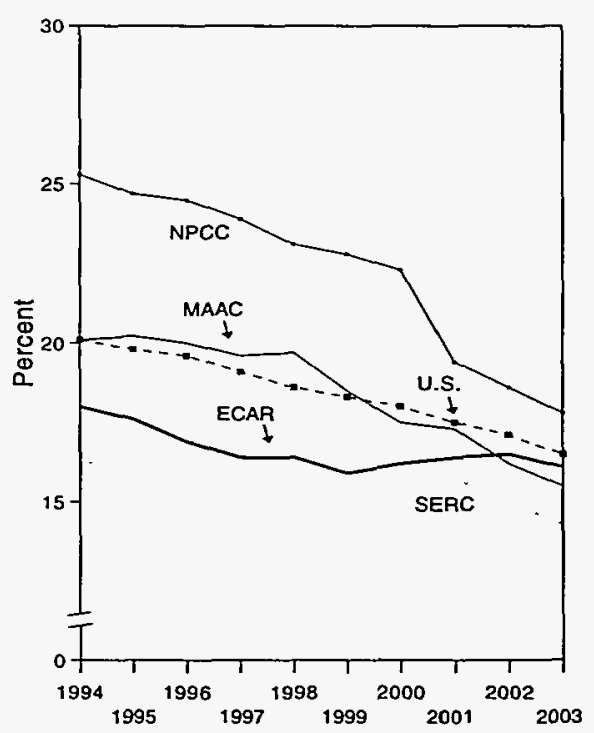

Figure A4. Projected Capacity Margin for the Western United States by NERC Region, 1994-2003

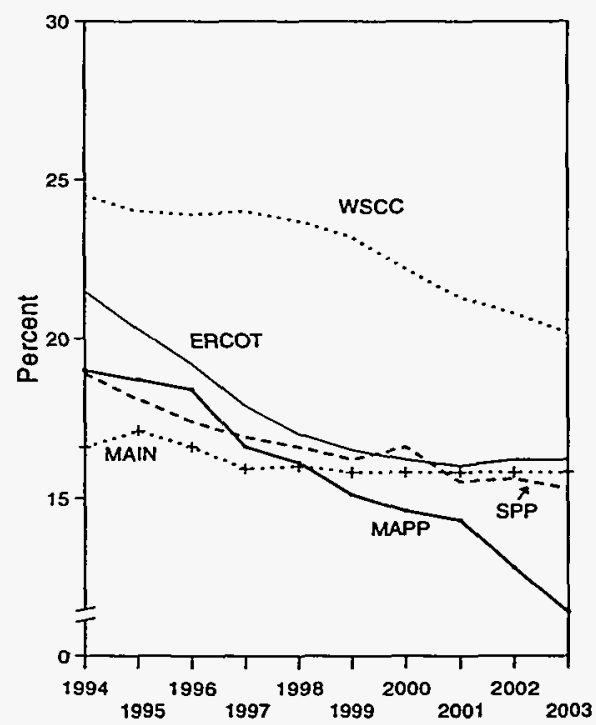

Endnotes and figure notes are at the end of the Appendix. 


\section{Annual Additions in Capability and Peak Demand}

Figure A5. Annual Net Additions in Net Summer Capability and Summer Peak Demand, 1973-1993

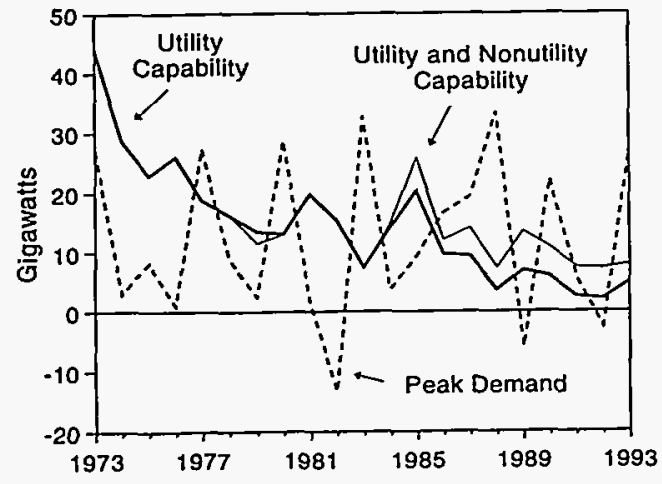

Figure A6. Annual Percentage Change in Electricity Sales, 1973-1993

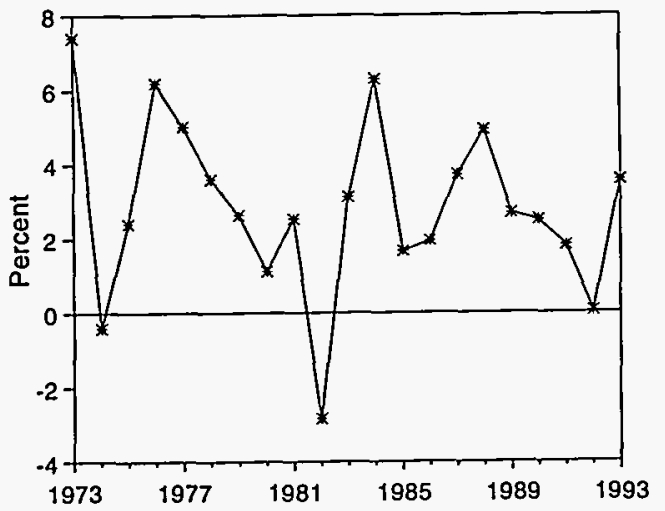

Figure A7. Projected Annual Net Additions in Net Summer Capability and Summer Peak Demand, 1994-2003

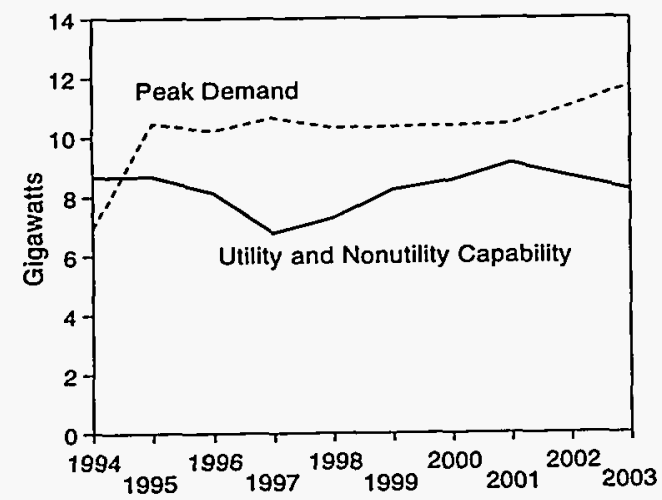

- Many factors affect actual and planned capacity margins and, therefore, the planning of an adequate electricity supply. On the demand side, electricity sales are an indication of how much electricity demand existed during a year. This data is useful in a historical look at capacity margins. Also useful are net additions to capability and peak demand. By reviewing these factors historically, their affect on future reliability can be assessed. These data are also helpful in projecting future peak demand and capacity needs.

- The year-to-year change in net capability includes yearly capacity additions as well as retirements. This change in net utility summer generating capability over the previous year has had a declining trend from 1973 to 1993 (Figure A5), dropping from a net gigawatt addition of 43.8 gigawatts in 1973 to 4.9 gigawatts in 1993. Net summer.capability in total had an average annual growth rate of 2.4 percent.

- From 1973 to 1985 , utilities had an average annual net capability increase of 19.9 gigawatts compared to 5.6 gigawatts from 1986 through 1993. Conversely, nonutility net capacity additions decreased an average of 0.1 gigawatts annually from 1973 through 1984 while increasing an average of 4.5 gigawatts for 1985 to 1993.

- Summer peak demand has had a fairly constant cyclical trend, with an average increase of 12.1 gigawatts per year. Peak demand has grown from 348.0 gigawatts in 1973 to 575.4 gigawatts in 1993, an average annual growth rate of 2.5 percent. The year-to-year change in peak demand fluctuates greatly, mostly due to weather that cannot be predicted.

- One indication of electricity demand is electricity sales. Sales have had an average annual growth rate of 2.6 percent from 1973 to 1993 , and the year-to-year percentage changes have ranged from 7.4 percent to -2.8 percent (Figure A6). Electricity sales fluctuate from year to year, and two important factors that affect changes in consumption are weather and the economy.

- Projected year-to-year changes show peak demand remaining steady during the latter part of the 1990's, while capability exhibits an upward trend during that time (Figure A7). Many of the capacity additions currently planned-around 60 percent in 1994-are nonutility facilities. ${ }^{[62]}$ Because of the short lead time required for building some nonutility facilities, it is possible for more nonutility additions during the latter half of the projection period. 


\section{Summer Peak Demand Forecasts}

- Demand is difficult to forecast because it is affected by many different factors, such as weather and the economy. In general, projected demand follows a trend similar to that exhibited in recent data. Projections of peak demand are not expected to be exact. Instead they are intended to provide a general idea of how much supply will be needed.

- The average annual growth rate in peak demand from 1978 to 1993 was 2.5 percent, similar to the average annual growth rate in total electricity sales of 2.4 percent during that same time period.

- High demand growth was experienced in the early 1970's and was expected to continue. For example, in 1973, summer peak demand was projected to go above 700 gigawatts by 1983 (Figure A8). In reality, peak demand remained much lower.

- By 1983, long-term expectations for the summer peak had been lowered. The 1-year-ahead forecast for 1983 was lower than the actual peak, and in both 1988 and 1993, the actual summer peaks were higher than the forecasts made both 1 year and 5 years ahead.

- The 1-year-ahead forecasts of summer peak demands varied from 9.9 percent above to 5.5 percent below the actual summer peak demand from 1973 to 1993 (Figure A9). The magnitude of the differences of actual versus forecast peak in the last 10 years has been less than in the 1973 through 1983 period.

- From 1983 through 1993, the general tendency has been to underestimate peak demand, while prior to 1983 overestimating almost always occurred. This underestimation is a concern for reliability, because higher-than-expected demand requires higher-thanexpected supply.

- Weather is the major factor affecting peak demand. In 1988, the Nation experienced one of the hottest summers in recent years, explaining the high actual peak demand. Conversely, moderate temperatures can also affect demand, as exhibited in 1992 when cool summer weather accompanied by moderate economic growth resulted in a decrease in peak from the previous year.

\author{
Figure A8. Actual vs. Projected Summer Peak \\ Demand, 1978-1993
}

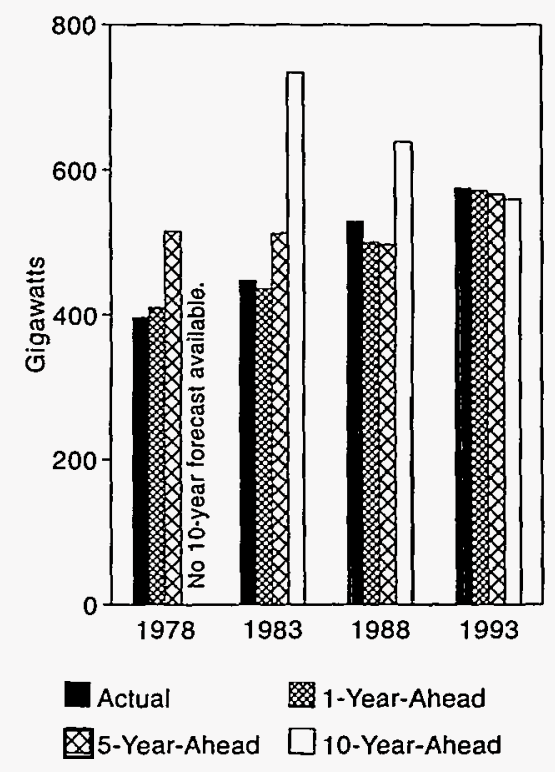

Figure A9. Difference Between One-Year Forecast and Actual Summer Peak Demand as a Percentage of Actual Summer Peak Demand, 1974-1993

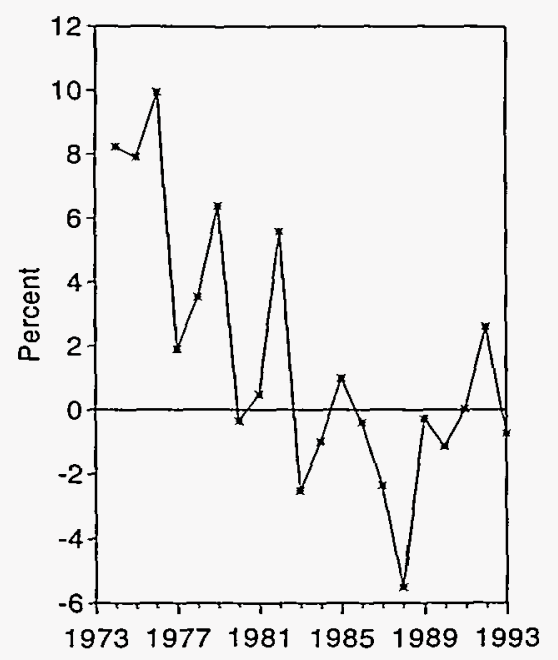

Endnotes and figure notes are at the end of the Appendix. 


\section{Demand-Side Management}

\section{Figure A10. Estimated Utility Demand-Side Management Energy Savings, 1989-1993}

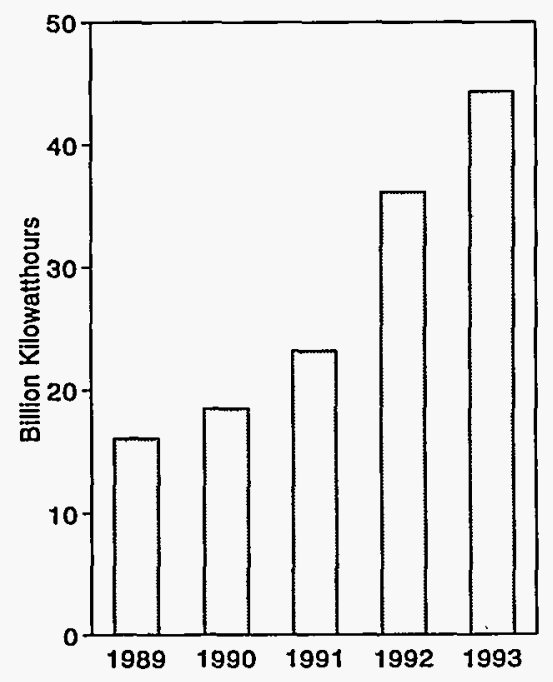

Figure A11. Demand-Side Management Load Objectives

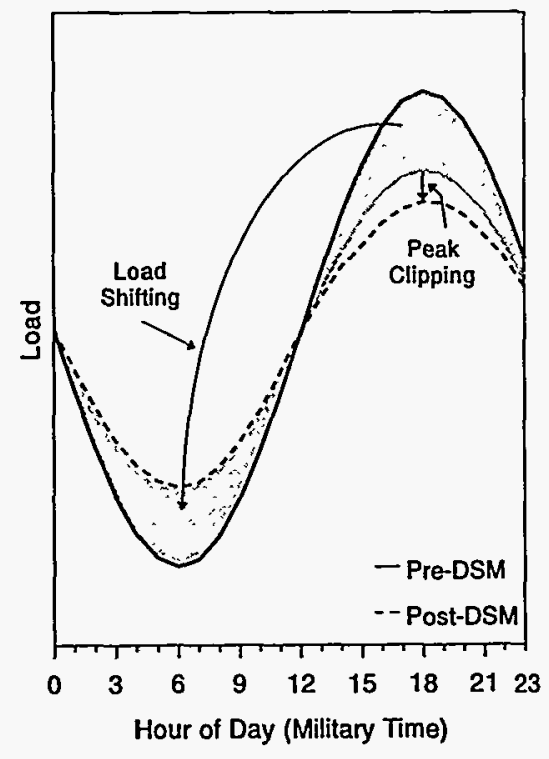

- Demand-side management (DSM) encompasses the planning, implementation, and monitoring of utility activities designed to motivate electricity consumers to modify their pattern of electricity usage, thereby impacting reliability by lessening the need for additional capacity generation and transmission lines.

- U.S. utilities in 1993 spent $\$ 2.8$ billion for DSM programs and estimated energy savings of 44.3 billion kilowatthours (Figure A10). By 1998, U.S. utilities currently expect to spend $\$ 3.9$ billion a year on DSM measures and are projected to save 90.1 billion kilowatthours in energy. ${ }^{[63]}$

- Actual peakload reduction due to DSM was estimated to be 14.8 gigawatts in 1990 . By 1993, peak load reduction reduced 23.2 gigawatts, with an average annual growth rate of 16.2 percent from 1990 through $1993 .^{[64]}$ Potential DSM savings are also projected to increase. By 1998, potential peakload reduction is projected to reach 32.7 gigawatts. ${ }^{[65]}$

- Peakload reduction is the result of two types of DSM programs (Figure A11): (1) peak clipping, which is simply reducing system peakload; and (2) load shifting, which involves shifting load from on-peak times of the day to off-peak times. These types of programs are important in view of reliability, because they reduce the utility's highest amount of demand.

- Actual peak demand had an average annual growth rate of 1.7 percent for the 6 years beginning in 1988 and ending in 1993, as compared to 2.6 percent for 1973 through 1978, a comparable time period before the first legislation encouraging DSM programs took effect. ${ }^{[66]}$ 


\section{Supply Trends}

\section{Utility Historical Data}

- The diversity of fuels for utility generation helps maintain capacity margins and reliability. Utilities can choose the mix of different generators to minimize fuel costs and account for fuel availability. Availability of fuel can be hampered by many occurrences, such as cold weather, strikes, and other constraints.

- Utility net summer capability is predominantly powered by conventional steam, which is 63.2 percent of existing capability (Figure A12). Since 1985, conventional steam capability has remained almost constant.

- Nuclear capability has grown from 22.7 gigawatts in 1973 to 99.0 gigawatts in 1993 . The average capacity factor of nuclear units has exhibited an increasing trend over the last two decades, from a low of 47.8 percent in 1974 to a high of 70.9 percent in $1992 .{ }^{[67]}$ However, four nuclear units have retired early because of poor performance and/or high costs (Fort St. Vrain, San Onofre 1, Trojan, and Yankee Rowe).

- Natural gas fuels the second largest amount of capability, much of which is used as peaking capability. ${ }^{[68]}$ Total natural gas consumption by electric utility plants in 1993 was 2.7 trillion cubic feet. ${ }^{[69]}$

- In the Texas Interconnection, natural gas-fired capability is 62.0 percent of the total capability. In the Western and Eastern Interconnections, however, the percentages are lower-23.3 percent and 13.4 percent, respectively. ${ }^{[70]}$ Because Texas is more dependent upon gas-fired capacity than the other interconnections, it has a larger proportion of firm contracts (Figure A13). Conversely, the Western Interconnection has almost no firm contracts, because its gas-fired capability is used as backup capability. Therefore, the Western Interconnection often purchases gas from the spot market as needed. The Eastern Interconnection has approximately 50 percent more gas-fired capability than the other two interconnections and purchases gas using many types of contracts.

- The projected capacity margin includes gas-fired capability with interruptible gas supplies; however, these supplies may not be available during peak gas demand (particularly during the winter). Many of these facilities can be fired with oil; however, the oil may be unavailable when needed.

\section{Figure A12. Utility Net Summer Capability by Prime Mover, 1973-1993}

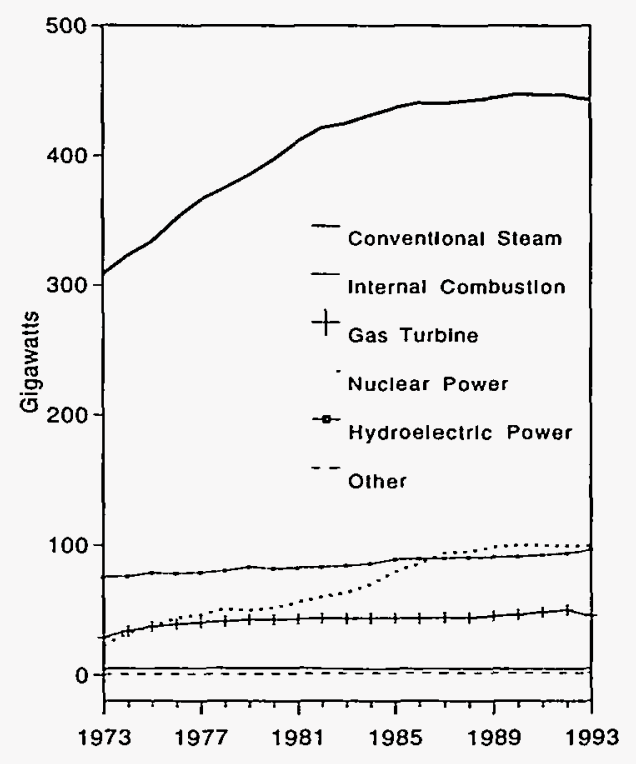

Figure A13. Utility Natural Gas Receipts by Contract Type and Interconnection, 1993

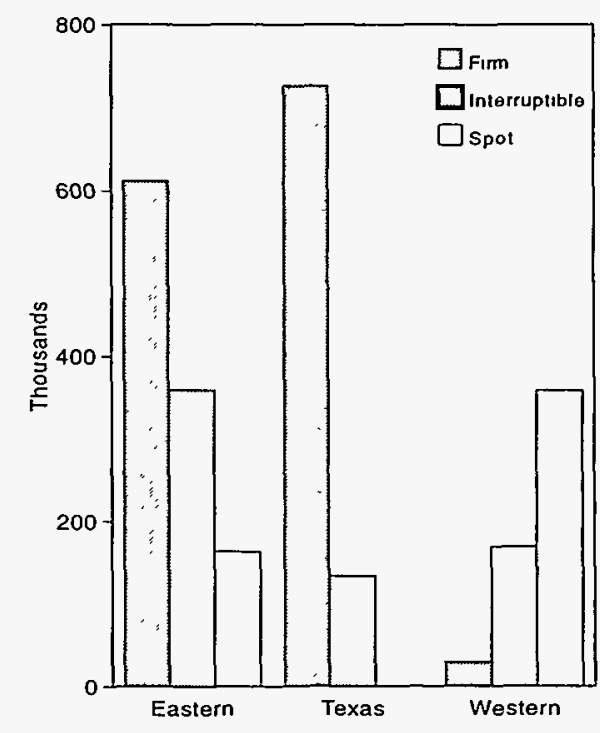

Endnotes and figure notes are at the end of the Appendix. 


\section{Supply Trends}

\section{Aging or Modified Supply}

Figure A14. Nameplate Capacity of Utility FossilFuel Steam Units and Nuclear Units by Age, 1993

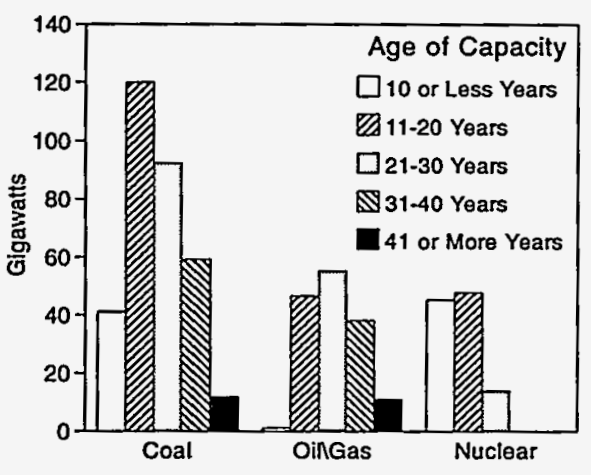

Figure A15. Proposed Utility Repowering and Plant Betterment, 1994-2003

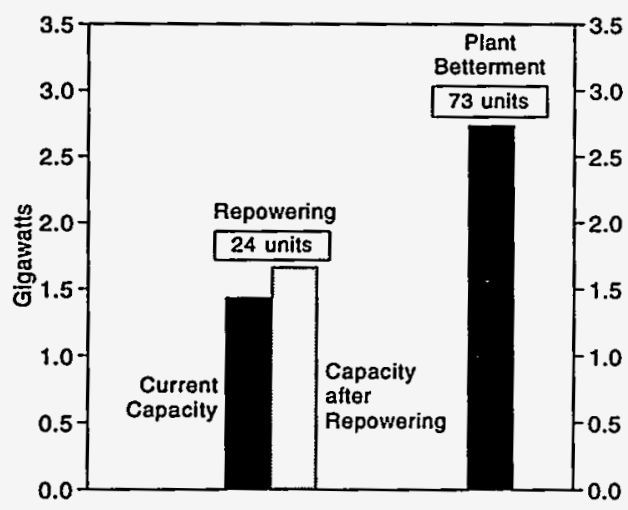

Figure A16. Utility Nameplate Capacity Affected by Phase I of CAAA90 by Compliance Method

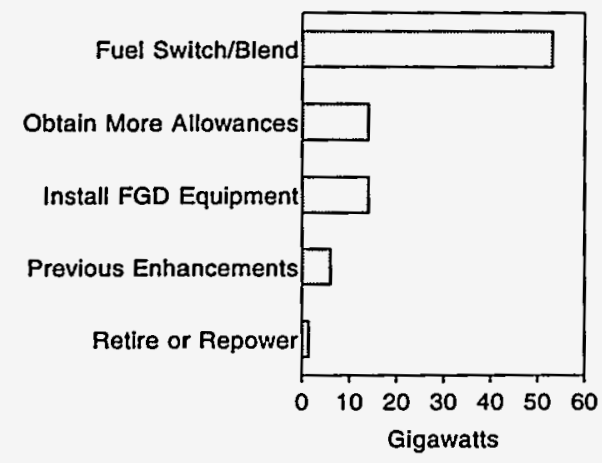

-In planning for the adequacy of an electric power system, it is useful to review the current supply as well as any expected changes to the supply, thereby evaluating how much supply is currently available and how much is expected to be available.

- About 25 percent of fossil-fired steam capacity is more than 30 years of age. Nuclear capacity, on the other hand, has only 1 unit with an age greater than 30 years (Figure A14). The average age (weighted by capacity) of coal-fired steam units is 22 years and of oil- and gas-fired units is 27 years, but the average weighted age of nuclear units is currently only 13 years. ${ }^{[71]}$ However, due to the cost associated with adding capacity, utilities want to optimize the availability of their units, even as these units age. Generating unit availability has shown a slight trend upward over the past several years. This was driven by a significant decline in equivalent forced outage rates..$^{[72]}$

- Units can improve their availability by altering their existing capacity in some way, i.e., repowering and plant betterment. At least 4.2 percent of utility fossil-fuel steam units anticipate plans for either repowering or plant betterment from 1994 through 2003 (Figure A15); however, it is expected that as 2003 gets closer, occurrences of these options will increase, and thereby increase existing capacity.

- The capability of some coal-fired units has been and is being reduced due to modification for compliance with the Clean Air Act Amendments of 1990 (CAAA90). By 1997, 14.1 gigawatts are expected to be retrofitted with flue gas desulfurization (FGD) equipment (Figure A16), which typically derates the capability by less than 2 percent. ${ }^{[33]}$ By 2000 , it is expected that 7.5 more gigawatts will be retrofitted, ${ }^{[74]}$ although the effect of these changes is small. This reduced capacity has not been incorporated into the U.S. capacity margin.

- Switching to low-sulfur coal with lower Btu values, particularly coal from the Powder River basin, can sometimes derate capacity. An analysis of eight case studies showed that two plants using Central Appalachian coal had no derating, and two out of six plants using Powder River Basin coal had deratings of 7.5 and 15.0 percent. $^{[75]}$ 


\section{Supply Trends}

\section{The Nonutility Industry}

- Nonutility generation increased dramatically in the mid- to late 1980 's, primarily as a result of the Public Utility Regulatory Policies Act of 1978 (PURPA-Figure A17). Questions about the effect of increased gridserving nonutility generation on reliability of the electric power industry have therefore become more prominent. ${ }^{[76]}$

- Anticipated future growth in grid-serving nonutility generation raises the question of whether these generators, including independent power producers, can be depended on to provide reliable power. They do not have the same obligation to serve as a franchised utility and, accordingly, do not share the responsibility to maintain capacity reserves.

- The contractual obligations of grid-serving nonutility generators contain various provisions to guarantee a facility's availability and performance. Performance guarantees, maintenance requirements, and dispatch provisions are typically included in such arrangements. The intent is to make nonutilities an integral part of the utility system.

- Under normal conditions, meeting load requirements does not pose problems for a utility even if some of the nonutility plants fail to operate. A utility retains sufficient reserves to meet the shortfalls and maintains buy/sell arrangements with neighboring utilities for emergency situations.

- Nonutility generation had an average annual growth rate of 16.2 percent from 1985 to 1993, with the addition of 35.2 gigawatts of capacity. Nonutility gridserving generation grew 541 percent between 1985 and 1993, with an average annual growth rate of 26.2 percent.

- Conventional steam, including coal-fired, oil-fired, and gas-fired facilities, provides the largest portion of nameplate capacity for nonutilities, ${ }^{[7]} 45.1$ percent in 1993 (Figure A18). In terms of primary fuels, nonutility capacity depends on a much higher percentage of natural gas and renewable fuels than does utility capacity. This corresponds to its use of gas turbine, combined cycle, hydroelectric power, and other related prime movers, as well as conventional steam from such renewables as wood.
Figure A17. Nonutility Generation, 1973-1993

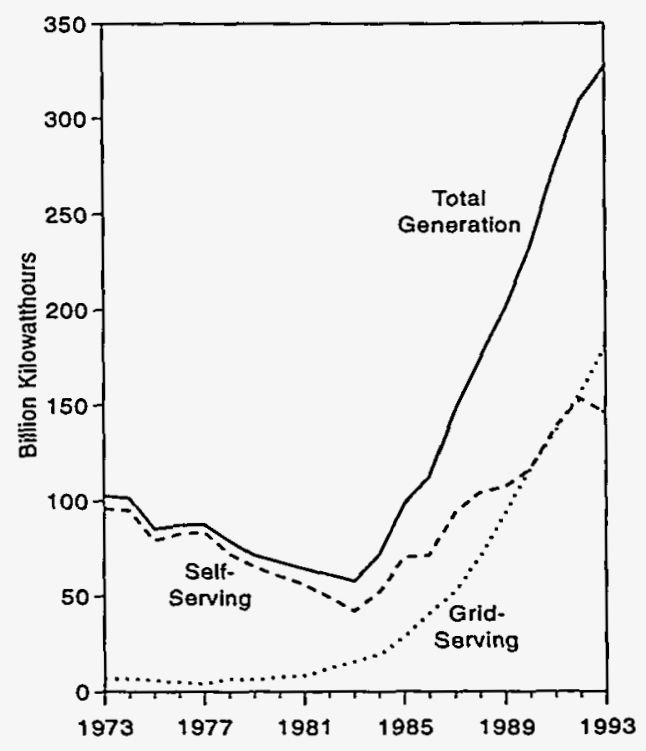

Figure A18. Nonutility Nameplate Capacity by Prime Mover, 1985-1993

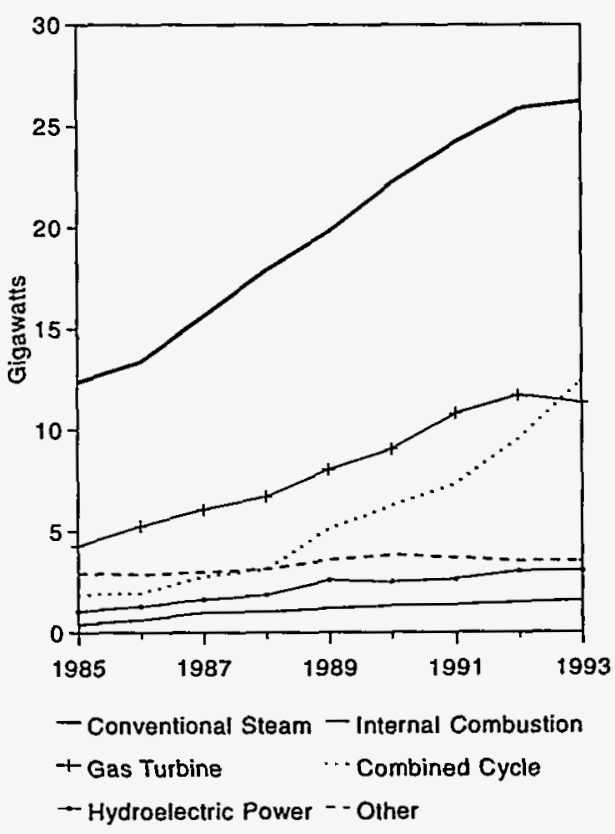

Endnotes and figure notes are at the end of the Appendix. 


\section{Supply Trends}

\section{Electricity Trade Between Utilities}

Figure A19. U.S. Wholesale Receipts and Sales to Ultimate Consumers of Electricity for Investor-Owned Utilities, 1986-1992

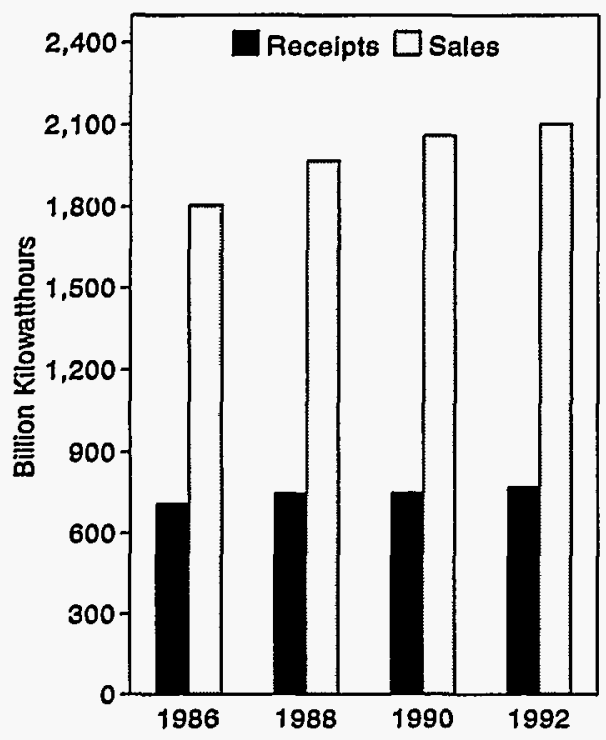

Figure A20. U.S. Electricity Trade with Canada and Mexico, 1973-1993

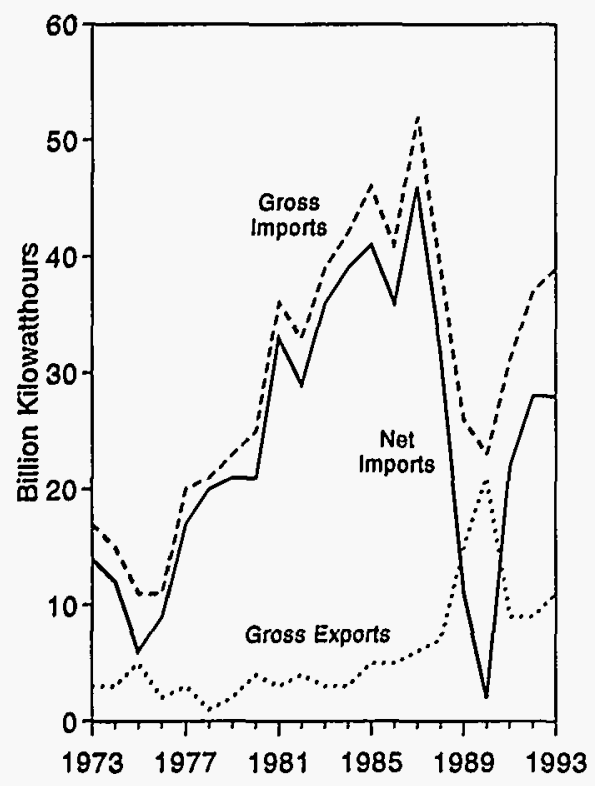

- Trading bulk power requires coordination of the entire electric power system to assure reliability. The effect of EPACT on this coordination is not clear. While some argue that more sellers will make it harder to coordinate the system, others contend that smaller and more diverse sellers will increase the stability of the system.

- Wholesale receipts by investor-owned utilities from utilities in other interconnections (interregional trade) are minimal when compared with bulk power trade within each interconnection (intraregional trade), and this also holds true for the individual NERC regions although to a lesser degree. The Texas Interconnection has the highest percentage of trade with other interconnections in each of the 4 years. Texas ranged from 2.0 percent to 7.4 percent while the other two interconnections remained below 1.4 percent. ${ }^{[78]}$

- Before electricity is sold to ultimate consumers, a large portion of it is traded. Between 1986 and 1992, wholesale receipts from bulk power trade by investorowned utilities as a proportion of sales to ultimate consumers ranged from 36 to 40 percent (Figure A19).

- International electricity trade with Canada and Mexico has historically been mainly gross imports, which increased steadily until 1987. After that time, gross imports decreased and gross exports increased to such an extent that they were almost equal in 1990 (Figure A20), because of increased domestic demand in the late 1980's in Ontario and a severe drought in Quebec. ${ }^{[79]}$ Purchases from Canada represented 94.9 percent of the gross imports in 1993. ${ }^{[80]}$

- Net imports (gross imports minus gross exports) comprise only around 1.0 percent of total U.S. electricity sales; however, they account for 7.1 percent of sales in NPCC and 6.3 percent in MAPP. ${ }^{[81]}$ In areas such as these, international electricity trade should be addressed in planning for reliability. 


\section{Endnotes}

${ }^{[52]}$ Nonutility nameplate capacity is used because capability is currently not collected for nonutility facilities. Nameplate capacity is (usually) slightly higher than capability.

[53] North American Electric Reliability Council, Electricity Supply \& Demand 1993-2002 (Princeton, NJ, June 1993), p. 12.

${ }^{154}$ The capacity margins presented in this report are gross capacity margins, that is, scheduled outages, forced outages, and other factors that affect availability of capacity are not considered.

${ }^{[55]}$ This capacity margin does not include transmission lines that make up the bulk power electric system, which should be considered in determining utility reliability. There are also other factors that are not considered, such as demand-side management and imports.

${ }^{[56]}$ For more information, see North American Electric Reliability Council, Electricity Supply \& Demand 1993-2002 (Princeton, NJ, June 1993), p. 12.

[57] North American Electric Reliability Council, Reliability Concepts (Princeton, NJ, February 1985), p. 18.

${ }^{[58]}$ North American Electric Reliability Council, Reliability Concepts (Princeton, NJ, February 1985), p. 18.

${ }^{[59]}$ North American Electric Reliability Council, Reliability Concepts (Princeton, N], February 1985), p. 18.

${ }^{\left[{ }^{60}\right]}$ See Table 1 for a list of the regional criteria.

${ }^{[61]}$ North American Electric Reliability Council, Reliability Assessment 1994-2003 (Princeton, NJ, September 1994$)$, p. 26.

${ }^{\left[{ }^{62]}\right]}$ Energy Information Administration, Inventory of Power Plants in the United States 1993, DOE/EIA-0095(93) (Washington, DC, December 1994), p. 27, and Energy Information Administration, Form EIA-867, "Annual Nonutility Power Producer Report" (1993).

${ }^{[63]}$ Energy Information Administration, Electric Power Annual 1993, DOE/EIA-0348(93) (Washington, DC, December 1994 ), p. 113.

${ }^{[64]}$ Energy Information Administration, Electric Power Annual 1993, DOE/EIA-0348(93) (Washington, DC, December 1994), p. 109.

${ }^{[65]}$ Energy Information Administration, Electric Power Annual 1993, DOE/EIA-0348(93) (Washington, DC, December 1994$)$, p. 112.

${ }^{[66]}$ North American Electric Reliability Council, Electricity Supply and Demand and predecessors (Princeton, NJ, 1972 through 1994).

${ }^{[67}$ Energy Information Administration, Monthly Energy Review, DOE/EIA-0035(94/06) (Washington, DC, June 1994$)$, p. 105.

${ }^{[68]}$ Energy Information Administration, Inventory of Power Plants in the United States 1993, DOE/EIA-0095(93) (Washington, DC, December 1994), Table 1.

[69] Energy Information Administration, Electric Power Annual 1993, DOE/EIA-0348(93) (Washington, DC, December 1994$),$ Table 20.

${ }^{[70]}$ Energy Information Administration, Inventory of Power Plants in the United States 1993, DOE/EIA-0095(93) (Washington, DC, December 1994), Table 14.

[71]Energy Information Administration, Form EIA-860, "Annual Electric Generator Report" (1993).

${ }^{[72]}$ North American Reliability Council, Reliability Assessment 1994-2003 (Princeton, NJ, September 1994), p. 16.

${ }^{173)}$ IEA Coal Research, FGD Performance and Experience on Coal-Fired Plants, IEACR/58 (London, England, July 1993 ), p. 52.

${ }^{[74]}$ Environmental Protection Agency, "SO 2 Phase I and II Boiler Compliance Methods" (Washington, DC, May 1994).

${ }^{[75]}$ Energy Information Administration, Electric Utility Phase I Acid Rain Compliance Strategies for the Clean Air Act Amendments of 1990, DOE/EIA-0582 (Washington, DC, March 1994), p. 22.

${ }^{[76]}$ For more information, see Energy Information Administration, The Changing Structure of the Electric Power Industry 1970-1991, DOE/EIA-0562 (Washington, DC, March 1993), and Energy Information Administration, Financial Impacts of Nonutility Power Purchases on Investor-Owned Electric Utilities, DOE/EIA-0580 (Washington, DC, June 1994).

[]$_{1}$ Net summer capability is currently not available for nonutilities.

${ }^{178]}$ Energy Information Administration, Electric Trade in the United States, DOE/EIA-0531 (Washington, DC, 1988 through 1994), and Energy Information Administration, Financial Statistics of Selected Investor Owned Electric Utilities, DOE/EIA-0437 (Washington, DC, 1992 and 1993).

${ }^{[79]}$ Energy Information Administration, U.S. Electricity Trade with Canada and Mexico, DOE/EIA-0553 (Washington, DC, January 1992), p. 31 .

${ }^{[80]}$ U.S. Department of Energy, Office of Fuels Programs, Form FE-781R, "Annual Report of International Electrical Export/Import Data" (1993).

${ }^{[81]}$ Energy Information Administration, Electric Power Annual 1993, DOE/EIA-0348(93) (Washington, DC, December 1994), Tables 55 and 62. 


\section{Figure and Table References and Notes}

Figure A1.

Source: North American Electric Reliability Council, Reliability Concepts (Princeton, NJ, February 1985) , p. 18.

\section{Figure A2.}

Notes: - Nonutility nameplate capacity was used in place of summer capability. - Only the grid-serving portion of nonutility capacity was included in calculating the capacity margin. - Nonutility data for 1973 through 1979 represent capacity in the industrial sector for plants of 10 megawatts or more only. - Nonutility data for 1980 through 1984 are estimates. - Nonutility data for 1985 through 1993 include all nonutilities.

Sources: Utility Net Summer Capability: 19731992-Energy Information Administration, Annual Energy Review 1993, DOE/EIA-0384(93) (Washington, DC, July 1994), p. 243. 1993-Energy Information Administration, Inventory of Power Plants in the United States, DOE/ELA-0095(93) (Washington, DC, December 1994, p. 24. Nonutility Nameplate Capacity and GridServing Generation: Edison Electric Institute, Statistical Yearbook of the Electric Utility Industry 1993 (Washington, DC, October 1994), pp. 7 and 15. Peak Demand: 19731977-North American Electric Reliability Council, Annual Review of Overall Reliability and Adequacy of the North American Bulk Power Systems (Princeton, NJ, 1974 through 1978). 1978-1979-North American Electric Reliability Council, Summary of Projected Peak Load, Generating Capability, and Fossil Fuel Requirements (Princeton, NJ, 1979 and 1980). 1980-1993-North American Electric Reliability Council, Electricity Supply and Demand and predecessors (Princeton, NJ, 1981 through 1994).

\section{Figures A3 and A4.}

Source: North American Electric Reliability Council, Electricity Supply and Demand 1994-2003 (Princeton, NJ, June 1994).

\section{Figure A5.}

Notes: - Nonutility nameplate capacity was used in place of summer capability. - Nonutility capacity includes both self-serving and grid-serving portions of capacity. - Nonutility data for 1973 through 1979 represent capacity in the industrial sector for plants of 10 megawatts or more only. - Nonutility data for 1980 through 1984 are estimates. • Nonutility data for 1985 through 1993 include all nonutilities.

Sources: Utility Net Summer Capability: 19731992-Energy Information Administration, Annual Energy Review 1993, DOE/EIA-0384(93) (Washington,
DC, July 1994), p. 243. 1993-Energy Information Administration, Inventory of Power Plants in the United States 1993, DOE/EIA-0095(93) (Washington, DC, December 1994), p. 24. Nonutility Nameplate Capacity: Edison Electric Institute, Statistical Yearbook of the Electric Utility Industry 1993 (Washington, DC, October 1994), p. 7. Peak Demand: 1973-1977-North American Electric Reliability Council, Annual Review of Overall Reliability and Adequacy of the North American Bulk Power Systems (Princeton, NJ, 1974 through 1978). 1978-1979-North American Electric Reliability Council, Summary of Projected Peak Load, Generating Capability, and Fossil Fuel Requirements (Princeton, NJ, 1979 and 1980). 19801993-North American Electric Reliability Council, Electricity Supply and Demand and predecessors (Princeton, NJ, 1981 through 1994).

Figure A6.

Sources: 1973-1992: Energy Information Administration, Annual Energy Review 1993, DOE/EIA-0384(93) (Washington, DC, July 1994), p. 239. 1993: Energy Information Administration, Electric Power Annual 1993, DOE/EIA-0348(93) (Washington, DC, December 1994) p. 91.

\section{Figure A7.}

Source: North American Electric Reliability Council, Electricity Supply and Demand 1994-2003 (Princeton, NJ, June 1994).

\section{Figures A8 and A9.}

Note: Percent difference represents the relative change in a quantity over a specified time period. It is calculated as follows: the difference between the forecasted value and the actual value is divided by the actual value and multiplied by 100 .

Sources: 1973-1977: North American Electric Reliability Council, Annual Review of Overall Reliability and Adequacy of the North American Bulk Power Systems (Princeton, NJ, 1974 through 1978). 1978-1979: North American Electric Reliability Council, Summary of Projected Peak Load, Generating Capability, and Fossil Fuel Requirements (Princeton, NJ, 1979 and 1980). 1980-1993: North American Electric Reliability Council, Electricity Supply and Demand and predecessors (Princeton, NJ, 1981 through 1994).

\section{Figure A10.}

Source: Energy Information Administration, Electric Power Annual 1993, DOE/ELA-0348(93) (Washington, DC, December 1994), Table 70. 
Figure A11.

Source: Energy Information Administration, Office of Coal, Nuclear, Electric and Alternate Fuels.

\section{Figure A12.}

Sources: 1973-1992: Energy Information Administration, Annual Energy Review 1993, DOE/EIA-0384(93) (Washington, DC, July 1994), p. 243. 1993: Energy Information Administration, Inventory of Power Plants in the United States 1993, DOE/EIA-0095(93) (Washington, DC, December 1994), Table 6.

\section{Figure A13.}

Source: Federal Energy Regulatory Commission, Form 423, "Monthly Report of Cost and Quality of Fuels for Electric Plants."

\section{Figures A14 through A15.}

Source: Energy Information Administration, Form EIA-860, "Annual Electric Generator Report."

\section{Figure A16.}

Note: These compliance methods are based on information obtained in late 1993.

Source: Energy Information Administration, Electric Utility Phase I Acid Rain Compliance Strategies for the Clean Air Act Amendments of 1990, DOE/EIA-0582 (Washington, DC, March 1994), p. 6.

\section{Figure A17.}

Notes: - Nonutility data for 1973 through 1979 represent capacity in the industrial sector for plants of
10 megawatts or more only. Nonutility data for 1980 through 1984 are estimates. - Nonutility data for 1985 through 1993 include all nonutilities.

Source: Edison Electric Institute, Statistical Yearbook of the Electric Utility Industry 1993 (Washington, DC, October 1994), p. 15.

\section{Figure A18.}

Source: Edison Electric Institute, Capacity and Generation of Non-Utility Sources of Energy (Washington, DC, 1986 through 1994).

\section{Figure A19.}

Sources: Wholesale Receipts: Energy Information Administration, Electric Trade in the United States, DOE/EIA-0531 (Washington, DC, 1988 through 1994). Sales to Ultimate Consumers: Energy Information Administration, Financial Statistics of Selected InvestorOwned Electric Utilities, DOE/EIA-0437 (Washington, DC, 1992 and 1993).

Figure A20.

Sources: 1973-1992: Energy Information Administration, Annual Energy Review 1993, DOE/EIA-0384(93) (Washington, DC, July 1994), p. 231. 1993: U.S. Department of Energy, Office of Fuels Programs, Form FE-781R, "Annual Report of International Electric Export/Import Data." 
Appendix B

The Economics of Electric Power Reliability 



\section{Appendix B}

\section{The Economics of Electric Power Reliability}

The following discussion only sketches some of the current results of research on reliability. The intention of this discussion is to present only some of the issues involved and results of that analysis. ${ }^{82}$

One of the most difficult problems when trying to decide what level of reliability for electricity supply is appropriate is estimating what the cost of disruptions to the system really is. This difficulty arises when directly estimating the demand for electricity and when trying to discover it using indirect methods.

\section{Types of Outage Costs ${ }^{83}$}

An outage occurs when the provision of electricity to a customer is interrupted and the demand for electricity by customers exceeds the supply of electricity. When this happens, there are costs to both the supplier and consumer of electricity. These costs can be grouped into three different categories:

Rationing cost: The cost of allocating the scarce supply of electricity when a shortage occurs; it is incurred by the utility. For example, the cost of a survey to help in determining customer priority during a shortage is a rationing cost.

Disruption cost: The direct cost of a shortage to the electricity consumer. This is the cost the consumer incurs over and above any revenue or value that would be foregone because of the shortage. Spoilage of inventory or loss of business because of a shortage are examples of disruption costs.

Lost surplus cost: A surplus cost is a hypothetical cost. It is the excess above the price of electricity that consumers are willing to pay for the electricity that was not supplied during a shortage and is independent of the price of electricity. For example, if a consumer would have been willing to pay 10 cents for a kilo- watthour of electricity that was not supplied, but the price of the electricity not supplied was only 6 cents, the surplus cost is 4 cents.

The total cost of an outage is the sum of these three different outage costs.

\section{Direct Estimation}

One way to estimate the costs of disruptions, especially for businesses, is to measure the cost of an outage to each business, including the extra costs incurred and the revenues lost as a result of the outage. This is often very costly to do because of the large number and different types of businesses involved in an outage. In addition, in countries with highly reliable electric power systems, such as the United States, there has been relatively little experience with outages, which further compounds the problem.

Direct estimation of costs is not very useful when it comes to residential customers because they usually have few direct costs. Other methods must be used in this case.

\section{Indirect Estimation}

For residential customers, the costs of outages are usually based on the value that an individual consumer places on the loss of electricity. Because there are no direct measures of these costs, they are particularly difficult to estimate. One approach is to survey residential customers and ask how much they value the lost electricity. In this case, consumers often overestimate the value of the lost electricity.

The use of surveys has also led to contradictory results, depending on how the questions were framed. When asked how much they are willing to pay for more reliability, residential customers often respond with

\footnotetext{
${ }^{82}$ For a more complete discussion of the economics of reliability, see Michael A. Crew, Chitru S. Fernando, and Paul R. Kleindorfer, "The Theory of Peak-Load Pricing: Survey and Synthesis," mimeo, April 1994, and Paul R. Kleindorfer and Chitru S. Fernando, "Peak-Load Pricing and Reliability Under Uncertainty," Journal of Regulatory Economics, Vol. 5, No. 1, (March 1993) pp. 5-23.

${ }^{83}$ This classification of outage costs was first presented in Paul R. Kleindorfer and Chitru S. Fernando, "Peak-Load Pricing and Reliability Under Uncertainty," Journal of Regulatory Economics, v. 5, no. 1 (March 1993), pp. 5-23.
} 
relatively low values. However, when asked how much they are willing to accept to be compensated for less reliability, they often respond with relatively high values. There is no theoretical basis for choosing between these alternative measures. ${ }^{84}$

\section{Estimating Lost Surplus Cost}

The most difficult cost to estimate is the lost surplus, because it cannot be measured directly. To measure this cost, the demand for electricity must be measured for each different group of consumers. To make the task less daunting, estimates of demands may be applied to similar groups of consumers served by different utilities, if evidence exists to support the similarity across utilities.

Fortuitously, as will be discussed later in this chapter, lost surplus costs may not have to be measured to determine the best combination of reliability of the electric power system and price of electricity. In these cases, the calculations can be simplified so that only measures of disruption and rationing costs, as well as the operating and capital costs of producing electricity facing the utility are required.

\section{Results of Analysis}

Some of the most recent research in economics analyzes the price that needs to be charged for electricity and the amount of electricity-producing capacity that needs to be available to maximize the well-being of society, when both the demand for and the supply of electricity are uncertain.

\section{Simple Case}

The analysis starts with a simple case where there is only a single technology to generate electricity and only a single, invariant demand for electricity by consumers. To simplify the analysis, it is also assumed that rationing and disruption costs are proportional to the amount of shortage when a disruption occurs and are the same for all consumers.

To maximize the well-being of society under these conditions, the costs associated with the loss of electricity service to an additional consumer during a shortage must equal the cost of an additional unit of electricityproducing capacity. More specifically, the price of electricity plus the marginal expected surplus loss to the last customer served when the shortage occurs, plus the marginal expected disruption and rationing cost minus any other production cost saved, must equal the marginal cost of an effective increase in capacity. This condition must be true when the optimal amount of electricity-producing capacity is in service: add capacity until its marginal cost is equal to the marginal cost of a loss of electricity service.

From this general rule for optimizing capacity and reliability, results can be obtained for the optimum loss of load probability and optimum price. In addition, if certain conditions are assumed about the demand for electricity and the value of the surplus loss, ${ }^{85}$ the results can be simplified, and, in the one case, can be expressed in terms of parameters that are potentially measurable. In the simplest case, the optimal loss of load probability equals the marginal cost of an effective addition to capital divided by the disruption cost plus the rationing cost plus the marginal cost of an effective addition to capital. The optimal price of electricity is the cost of operating additional capacity plus the marginal cost of an effective addition to capital. Under slightly more complicated assumptions, the marginal cost of an effective addition to capital in the preceding results is multiplied by the expected value of uncertainty, given

\footnotetext{
${ }^{84}$ Mohan Munasinghe and Arun P. Sanghvi, "Reliability of Electric Supply, Outage Costs and Value of Service," The Energy Journal, v. 9. special issue on electricity reliability (1988), pp. 1-18.

${ }^{85}$ These conditions are that the demand function include uncertainty as an additive or a multiplicative term and that the fraction of willingness to pay (price plus surplus loss) lost when excess demand occurs is negligible.
} 
that the demand for electricity is greater than its supply. ${ }^{86}$

\section{More Complex Cases}

The preceding analysis is extended to include diverse technologies to generate electricity and multiple time periods with different demands in each. The technologies may include not only different processes to produce electricity but also different parts of the production process, for example, transmission and distribution. They may also include integrated resource management programs. The latter considers alternatives to generating electricity that produce the services provided by electricity. Integrated resource planning includes demand-side management, which reduces the demand for electricity, in a sense "creating" generating capacity. ${ }^{87}$

The results for optimal price, capacity, and reliability, in the case of multiple time periods and technologies, are straightforward extensions of the single time period and technology case. Thus the results of the single time period and technology case are instructive in more general cases as well.

The preceding is only one approach to the analysis of reliability. There are other theoretical approaches to analyze reliability including real-time pricing, priority service, and self-rationing. These alternatives have not been discussed here.

\footnotetext{
${ }^{86}$ Results that are independent of the form of the demand function and the fraction of marginal willingness to pay lost when excess demand occurs are very complex. In general,

$$
L=[k-(w-P)] /\left[k-(w-P)+(b+r) *\left[1-\left(D_{s} / D_{n}\right)\right]\right]
$$

the optimal loss of load probability, $L$, equals the marginal cost of an effective increase in capacity, $k$, minus the expected value of the excess of willingness to pay over price, $(w-P)$, divided by $k$ minus $(w-P)$ plus the marginal expected disruption and rationing costs, $(b+r)$, times one minus the expected change in the demand for electricity given a change in the price of electricity during a shortage, $D_{s}$ divided by the expected change in the demand for electricity given a change in the price of electricity when there is not a shortage of electricity, $D_{n}$.
}

$$
P=c+k-(w-P)-(b+r) *\left[1-\left(D_{s} / D_{n}\right)\right]
$$

the optimal price of electricity, $\mathrm{P}$, equals the marginal operating cost of the electricity-producing capacity, $\mathrm{c}$, plus $\mathrm{k}$ minus ( $w$ - $\mathrm{P}$ ) minus $(b+r)$ times $\left[1-\left(D_{s} / D_{n}\right)\right]$.

$$
k=L^{*}[(P-c)+(b+r)]+(w-P)
$$

the optimal capacity is the amount where $k$ equals $L$ times $(P-c)$ plus $(b+r)$, plus $(w-P)$.

${ }^{87}$ For example, insulation helps keep a building cooler in the summer, thus substituting for air conditioning to cool the building. The way that demand-side management is represented by Kleindorfer and Fernando only considers rebates as transfers between the utility and consumers; they do not affect the decisions of consumers to participate in demand-side management programs. 
• 


\section{Glossary}

Actual Peak Reduction: The actual reduction in annual peak load (measured in kilowatts) achieved by consumers that participate in a utility DSM program. It reflects the changes in the demand for electricity resulting from a utility DSM program that is in effect at the same time the utility experiences its annual peak load, as opposed to the installed peak load reduction capability (i.e., potential peak reduction). It should account for the regular cycling of energy efficient units during the period of annual peak load.

Adequacy: The ability of the bulk electric power system to supply the aggregate electrical demand and energy requirements of consumers at all times.

Bulk Power System: A term describing all electric generating plants, transmission lines, and equipment.

CAAA90: The Clean Air Act Amendments of 1990.

Capability: The maximum load that a generating unit, generating station, or other electrical apparatus can carry under specified conditions for a given period of time without exceeding approved limits of temperature and stress.

Capacity: The amount of electric power delivered or required for which a generator, turbine, transformer, transmission circuit, station, or system is rated by the manufacturer.

Capacity Margin: An indication of the amount of capacity available to provide for scheduled maintenance, emergency outages, system operating requirements, and unforeseen electricity demand.

Coal: A black or brownish-black solid combustible substance formed by the partial decomposition of vegetable matter without access to air. The rank of coal, which includes anthracite, bituminous coal, subbituminous coal, and lignite, is based on fixed carbon, volatile matter, and heating value. Coal rank indicates the progressive alternation from lignite to anthracite. Lignite contains approximately 9 to 17 million Btu per ton. The contents of subbituminous and bituminous coal range from 16 to 24 million Btu per ton and from 19 to 30 million Btu per ton, respectively. Anthracite contains approximately 22 to 28 million Btu per ton.
Coincidental Peak Load: The sum of two or more peakloads that occur in the same time interval.

Combined Cycle: An electric generating technology in which electricity is produced from otherwise lost waste heat exiting from one or more gas (combustion) turbines. The exiting heat is routed to a conventional boiler or to a heat recovery steam generator for utilization by a steam turbine in the production of electricity. This process increases the efficiency of the electric generating unit.

Consumption (Fuel): The amount of fuel used for gross generation, providing standby service, start-up and/or flame stabilization.

Control Area: An electric system that directly controls its generation to continuously meet demand and fulfill exchange obligations and that helps regulate and stabilize the frequency of its interconnection's electric current.

Demand (Electric): The rate at which electric energy is delivered to or by a system, part of a system, or piece of equipment, at a given instant or averaged over any designated period of time.

Demand-Side Management (DSM): The planning, implementation, and monitoring of utility activities that are designed to influence consumer use of electricity in ways that will produce desired changes in a utility's load shape, including direct load control, interruptible load, conservation, and other demand-side management categories. Demand-side management includes utilityadministered programs that are designed to reduce load growth, and any other programs designed for strategic load growth.

DSM: Demand-side management.

Electric Utility: A corporation, person, agency, authority, or other legal entity or instrumentality that owns and/or operates facilities within the United States, its territories, or Puerto Rico for the generation, transmission, distribution, or sale of electric energy primarily for use by the public and files forms listed in the Code of Federal Regulations, Title 18, Part 141. Facilities that qualify as cogenerators or small power 
producers under the Public Utility Regulatory Policies Act (PURPA) are not considered electric utilities.

Energy: The capacity for doing work as measured by the capability of doing work (potential energy) or the conversion of this capability to motion (kinetic energy). Energy has several forms, some of which are easily convertible and can be changed to another form useful for work. Most of the world's convertible energy comes from fossil fuels that are burned to produce heat that is then used as a transfer medium to mechanical or other means in order to accomplish tasks. Electrical energy is usually measured in kilowatthours, while heat energy is usually measured in British thermal units.

EIA: Energy Information Administration.

Facility: An existing or planned location or site at which prime movers, electric generators, and/or equipment for converting mechanical, chemical, and/or nuclear energy into electric energy are situated, or will be situated. A facility may contain more than one generator of either the same or different prime mover type.

Federal Energy Regulatory Commission (FERC): A quasi-independent regulatory agency within the Department of Energy having jurisdiction over interstate electricity sales, wholesale electric rates, hydroelectric licensing, natural gas pricing, oil pipeline rates, and gas pipeline certification.

Firm Electricity Trade: Firm sales usually involve the sale of capacity, meaning that either the associated energy will be taken by the purchaser or the purchaser will pay for the capacity during those periods when the energy is not taken. The delivery is scheduled as part of the normal operating conditions of the affected electric systems. The capacity offered in these transactions is usually for a specified period of time and negotiated in advance of the trade.

Flue Gas Desulfurization Unit (Scrubber): Equipment used to remove sulfur oxides from the combustion gases of a boiler plant before discharge to the atmosphere. Chemicals, such as lime, are used as the scrubbing media.

Forced Outage: The shutdown of a generating unit, transmission line or other facility, for emergency reasons or a condition in which the generating equipment is unavailable for load due to unanticipated breakdown.

Forced Outage Rate: The rate of shutdown of a generating unit, transmission line, or other facility, for emergency reasons or a condition in which the generating equipment is unavailable for load because of unanticipated breakdown.

Fossil Fuel: Any naturally occurring organic fuel, such as petroleum, coal, and natural gas.

Frequency Regulation: The control of an interconnection's frequency through the combined efforts of the control areas' generation control.

Fuel: Any substance that can be burned to produce heat; also, materials that can be fissioned in a chain reaction to produce heat.

Gas Turbine Plant: A plant in which the prime mover is a gas turbine. A gas turbine typically consists of an axial-flow compressor which feeds compressed air into one or more combustion chambers where liquid or gaseous fuel is burned. The resulting hot gases are expanded through the turbine, causing it to rotate. The rotating turbine shaft drives the compressors as well as the generator, producing electricity.

Generating Unit: Any combination of physically connected generator(s), reactor(s), boiler(s), combustion turbine(s), or other prime mover(s) operated together to produce electric power.

Generation (Electricity): The process of producing electric energy from other forms of energy; also, the amount of electric energy produced, expressed in watthours (Wh).

Gross Generation: The total amount of electric energy produced by the generating units at a generating station or stations, measured at the generator terminals.

Net Generation: Gross generation less the electric energy consumed at the generating station for station use.

Generator: A machine that converts mechanical energy into electrical energy.

Generator Nameplate Capacity: The full-load continuous rating of a generator, prime mover, or other electric power production equipment under specific conditions as designated by the manufacturer. Installed generator nameplate rating is usually indicated on a nameplate physically attached to the generator.

Gigawatt (GW): One billion watts of capacity. 
Grid: The layout of the electrical transmission system.

Inadvertent Energy Balancing: A control area's accounting of its inadvertent interchange. Inadvertent interchange is the accumulated difference between actual and scheduled interchange. Adjacent control areas must agree on these values daily. The difference is repaid usually with energy, not money.

Interchange Scheduling: The actions taken by two control areas to transfer electric power, capacity, and/or energy from one to another. The schedule consists of an agreement on the transfer's size (megawatts), start and end times, and degree of firmness (energy only or with capacity).

Kilowatt (kW): One thousand watts of capacity.

Kilowatthour (kWh): One thousand watthours of electrical energy.

Load (Electric): The amount of electric power delivered or required at any specific point or points on a system. The requirement originates at the energy-consuming equipment of the consumers.

Load Following: An electric system's ability to regulate its generation to follow the minute-to-minute changes in its customers' demand.

Load-Shifting: DSM programs designed to shift load from on-peak times of the day to off-peak times.

Loss of Load Probability (LOLP): A measure of the expectation that system demand will exceed capacity during a given period, often expressed as the expected number of days per year.

Megawatt (MW): One million watts of capacity.

Megawatthour (MWh): One million watthours of electric energy.

$\mathrm{NO}_{\mathbf{x}}$ : Nitrogen oxides.

Natural Gas: A naturally occurring mixture of hydrocarbon and nonhydrocarbon gases found in porous geological formations beneath the earth's surface, often in association with petroleum. The principal constituent is methane.

Net Summer Capability: The steady hourly output, which generating equipment is expected to supply to system load exclusive of auxiliary power, as demonstrated by tests at the time of summer peak demand.
Noncoincidental Peak Load: The sum of two or more peakloads on individual systems that do not occur in the same time interval.

Nonfirm Electricity Trade: These transactions are typically for short periods and subject to curtailment or cessation of delivery by the supplier in accordance with prior agreèments or under specified conditions. Nonfirm sales are sometimes called energy, economy, or interruptible sales.

Nonutility Power Producer: A corporation, person, agency, authority, or other legal entity or instrumentality that owns electric generating capacity and is not an electric utility. Nonutility power producers include qualifying cogenerators, qualifying small power producers, and other nonutility generators (including independent power producers) without a designated franchised service area, and which do not file forms listed in the Code of Federal Regulations, Title 18, Part 141.

North American Electric Reliability Council (NERC): A council formed in 1968 by the electric utility industry to promote the reliability and adequacy of the bulk power supply in the electric utility systems of North America. NERC consists of nine regional councils and encompasses essentially all the power regions of the contiguous United States, Canada, and a small portion of Mexico. There is also one affiliate member in Alaska, the Alaskan System Coordination Council.

Operating Reserve: The reserve generating capacity necessary to allow an electric system to recover from generation failures and provide for load following and frequency regulation. It consists of spinning and nonspinning capacity.

Outage: The period during which a generating unit, transmission line, or other facility is out of service.

Peak Demand: The maximum load during a specified period of time.

Peak Clipping: DSM programs that are designed to reduce system peak load.

Percent Difference: The relative change in a quantity over a specified time period. It is calculated as follows: the difference between the current value and the previous value is divided by the previous value and multiplied by 100 .

Plant Betterment: Plant restoration or refurbishment that is sometimes called life extension or performance optimization. 
Petroleum: A mixture of hydrocarbons existing in the liquid state found in natural underground reservoirs, often associated with gas. Petroleum includes fuel oil No. 2, No. 4, No. 5, No. 6; topped crude; Kerosene; and jet fuel.

Plant: A facility at which are located prime movers, electric generators, and auxiliary equipment for converting mechanical, chemical, and/or nuclear energy into electric energy. A plant may contain more than one type of prime mover. Electric utility plants exclude facilities that satisfy the definition of a qualifying facility under the Public Utility Regulatory Policies Act of 1978.

Plant-Use Electricity: The electric energy used in the operation of a plant. This energy total is subtracted from the gross energy production of the plant; for reporting purposes the plant energy production is then reported as a net figure. The energy required for pumping-storage plants is, by definition, subtracted, and the energy production for these plants is then reported as a net figure.

Potential Peak Reduction: The potential annual peak load reduction (measured in kilowatts) that can be deployed from Direct Load Control, Interruptible Load, Other Load Management, and other DSM Program activities. It represents the load that can be reduced either by the direct control of the utility system operator or by the consumer in response to a utility request to curtail load. It reflects the installed load reduction capability, as opposed to the Actual Peak Reduction achieved by participants, during the time of annual system peak load.

Power: The rate at which energy is used.

Prime Mover: The engine, turbine, water wheel, or similar machine that drives an electric generator; or, for reporting purposes, a device that converts energy to electricity directly (e.g., photovoltaic solar and fuel cells).

Reactive Power Generation: The production of electric current that leads or lags the phase of the electric voltage. Reactive power supplies the charging power for electromagnetic loads and the reactive needs of the transmission system.

Reliability: The degree to which the performance of the elements of a system results in power being delivered to consumers within accepted standards and in the amount desired. The degree of reliability may be measured by the frequency, duration, and magnitude of adverse effects on consumer service.

Repowering: The partial or complete replacement of the existing steam supply system with a new (and usually technologically different) steam supply system. Most other systems and components, including the steam-turbine generator, are refurbished and reused.

Retail Wheeling: The transmission of electricity from a wholesale supplier to a retail customer by a third party.

Security: The ability of the bulk electric power system to withstand sudden disturbances and remain in operation.

$\mathrm{SO}_{2}$ : Sulfur dioxide.

Spot Market: A market where goods are traded for (essentially) immediate delivery.

Steam-Electric Plant (Conventional): A plant in which the prime mover is a steam turbine. The steam used to drive the turbine is produced in a boiler where fossil fuels are burned.

Stranded Investment: Investment with a cost recovery schedule that was initially approved by regulatory action that subsequent regulatory action has rendered not practically recoverable.

Sulfur: One of the elements present in varying quantities in coal which contributes to environmental degradation when coal is burned. In terms of sulfur content by weight, coal is generally classified as low (less than or equal to 1 percent), medium (greater than 1 percent and less than or equal to 3 percent), and high (greater than 3 percent). Sulfur content is measured as a percent by weight of coal on an "as received" or a "dry" (moisture-free, usually part of a laboratory analysis) basis.

Time Error Correction: An offset to the interconnection's frequency to correct for the time error that accumulates on electric clocks.

Valley-Filling: Demand-side management programs that seek to increase off-peak electricity consumption (without necessarily reducing on-peak demands).

Voltage Control: The control of transmission voltage through adjustments in generator reactive output and transformer taps, and by switching capacitors and inductors on the transmission and distribution systems. 
Watthour (Wh): An electrical energy unit of measure equal to 1 watt of power supplied to, or taken from, an electric circuit steadily for 1 hour.

Wholesale Sales: Energy supplied to other electric utilities, cooperatives, municipals, and Federal and State agencies for resale to ultimate consumers.
Wholesale Wheeling: The transmission of electricity from a wholesale supplier to another wholesale supplier by a third party. 